FARM MACHINERY LABORATORY MANUAL

SCOATES 


\section{FARM MACHINERY LABORATORY MANUAL}

D. SCOATES A. E.

Professor Agricultural Engineering Agricultural and Mechanical College of Texas

Member American Society Agricultural Engineers

FOURTH EDITION 


\section{INSTRUCTIONS TO STUDENTS.}

The first exercises and in fact the largest part of those in the book are to get the student familiar with the different parts of the machine, the principal differences in the various makes of the same type of machine and the function of each part. For these exercises there are questions asked, the answer to which the student must determine and jot down aside of the question. Blank spaces are left for these notations, or, if no blank space is left, the part of the question not applying to the machine can be crossed out. Sufficient machines of the same kind should be gone over to fill out all of the report sheets for that machine. After the report blanks for one kind of machine, such as walking plows or mowers, etc., are filled out, then the student should present himself to the instructor for a quiz on that machine. A grade will then be given.

In the case of assembling and testing exercises the student does the exercise as per instructions in the manual and additional instructions from the instructor. All results should be carefully tabulated in manual.

Each student will need a manual and a pocket tape. As soon as getting the manual the student should write his name on it in ink thus insuring its return in case of loss. Not more than three students should work together if all are to get the maximum benefit of the course.

In using the machinery and apparatus in the laboratory, take care of it as well as you would if it were your own. Keep in mind that, while the machinery is loaned to us and the apparatus belongs to the State, yet there are many other students coming after you and they too wish to have good machinery and apparatus to use.

Do not rush through your laboratory work or do not loaf. Work right along making each moment count for the most. Get all you can out of the laboratory worik. Do not run to the instructor with every little question, but try to rely upon yourself. Remember that the laboratory work is built on the assumption that you have the class room work in good shape; if you fail there, you are lost here. 


\section{WALKING PLOWS.}

General Information.

Exercise No. 1.

Trade name and number?

Manufacturer

Address?

Size? inches.

\section{Moldboard.}

Material-steel, soft centered steel, chilled cast iron?

Solid, slat or rod?

Type-stubble, sod or general purpose?

Which way is the moldboard polished?

Is shin reinforced?

\section{Share.}

Point reinforced?

Bearing at wing? inch.

How many bolts hold share on?

Amount of vertical suction?

Amount of horizontal suction?

\section{Landside.}

${ }^{*}$ High, medium, low?

Heel reinforced?

Reinforcement removable?

Is it perpendicular to plane of plow bottom? Frog.

Material-steel, cast iron or malleable?

Is it large or small?

\section{Beam.}

Meight of hitch? $\left\{\begin{array}{l}\text { maximum } \\ \text { minimum }\end{array}\right.$

Clevis well made?

Can adjustment of hitch in horizontal and vertical directions be easily made?

\section{Handles.}

Material-wood or steel?

How connected to plow?

Can they be adjusted?

*High above 5 in.; Medium 4 in. to 5 in.; low less than 4 in. 
WALKING PLOWS.

\section{General Information.}

Exercise No. 1.

Trade name and number?

Manufacturer

Address?

Size? inches.

\section{Moldboard.}

Material-steel, soft centered steel, chilled cast iron? Solid, slat or rod?

Type-stubble, sod or general purpose?

Which way is the moldboard polished?

Is shin reinforced?

\section{Share.}

Point reinforced?

Bearing at wing? inch.

How many bolts hold share on?

Amount of vertical suction? inch

Amount of horizontal suction? inch

\section{Landside.}

*High, medium, low?

Heel reinforced?

Reinforcement removable?

Is it perpendicular to plane of plow bottom? Frog.

Material-steel, cast iron or malleable?

Is it large or small?

\section{Beam.}

Material-wood or steel?

Height of hitch? $\left\{\begin{array}{l}\text { maximum } \\ \text { minimum }\end{array}\right.$

Clevis well made?

Can adjustment of hitch in horizontal and vertical directions be easily made?

Handles.

Material-wood or steel?

How connected to plow?

Can they be adjusted?

*High above 5 in.; Medium 4 in. to 5 in.; low less than 4 in. 


\section{WALKING PLOWS.}

\section{General Information.}

Exercise No. 1.

Trade name and number?

Manufacturer

Address?

Size? inches.

\section{Moldboard.}

Material-steel, soft centered steel, chilled cast iron?

Type-stubble, sod or general purpose?

Which way is the moldboard polished?

Is shin reinforced?

Share.

Point reinforced?

Bearing at wing? -inch.

How many bolts hold share on?

Amount of vertical suction? inch

Amount of horizontal suction? inch

\section{Landside.}

*High, medium, low?

Heel reinforced?

Reinforcement removable?

Is it perpendicular to plane of plow bottom?

\section{Frog.}

Material-steel, cast iron or malleable?

Is it large or small?

\section{Beam.}

Material-wood or steel?

Height of hitch? $\left\{\begin{array}{l}\text { maximum } \\ \text { minimum }\end{array}\right.$

Clevis well made?

Can adjustment of hitch in horizontal and vertical directions be easily made?

\section{Handles.}

Material-wood or steel?

How connected to plow?

Can they be adjusted?

\section{Miscellaneous.}

Which of the plows studied do you prefer?.-...-*High above 5 in.; Medium 4 in. to 5 in.; low less than 4 in. 
WALKING HILLSIDE PLOWS.

General Information.

Exercise No. 2.

Trade name and number?

Manufacturer?

Address?

Size? -inches.

\section{Moldboard.}

Material-steel, soft centered steel or chilled cast iron?

Which way is moldboard polished?

Is shin reinforced?

How does the shape differ from that of a common walking plow?

Share.

Point reinforced?

Bearing at wing? inch.

How many bolts hold share on?

Amount of vertical suction? -inch

Amount of horizontal suction? inch.

\section{Landside.}

High, medium or low?

Heel reinforced? . . . .

Frog.

Material-steel, cast iron or malleable?

Is it large enough for its purpose?

Can locking device be adjusted to wear?

Is hinge at point substantial and easily repaired?

\section{Beam.}

Material-wood or steel.

Height of hitch? $\left\{\begin{array}{l}\text { maximum } \\ \text { minimum }\end{array}\right.$

Clevis well made?

Can adjustment of hitch in horizontal and vertical directions be easily made?

Handles.

Material-wood or steel.

How connected to plow?

Can they be adjusted?

\section{Miscellaneous.}

Do you understand how the plow is operated and what are its advantages? 


\section{WALKING MIDDLEBREAKER.}

General Information.

Exercise No. 3 .

Trade name and number?

Manufacturer?

Address?

Size? inches.

\section{Moldboard.}

Material-steel, soft centered steel or chilled cast iron?

Which way is moldboard polished?

Is shin reinforced?

Share.

Point reinforced?

Bearing at wing? inch.

How many bolts hold share on?

Frog.

Material-steel, cast iron or malleable?

Is it large enough for its purpose?

\section{Rudder.}

Has middlebreaker a rudder?

Is it reinforced?

Beam.

Material-wood or steel?

Height of hitch? $\left\{\begin{array}{l}\text { maximum } \\ \text { minimum }\end{array}\right.$

Clevis well made?

Can adjustment of hitch in horizontal and vertical directions be easily made?

\section{Handles.}

Materials-wood or steel?

How connected to plow?

Can they be adjusted? 


\section{WALKING MIDDLEBREAKER.}

General Information.

Exercise No: 3 .

Trade name and number?

Manufacturer?

Address?

Size? inches.

Moldboard.

Material-steel, soft centered steel or chilled cast iron?

Which way is moldboard polished?

Is shin reinforced?

Share.

Point reinforced?

Bearing at wing? inch.

How many bolts hold share on?

Frog.

Material-steel, cast iron or malleable?

Is it large enough for its purpose?

Rudder.

Has middlebreaker a rudder?

Is it reinforced?

\section{Beam.}

Material-wood or steel?

Height of hitch? $\left\{\begin{array}{l}\text { maximum } \\ \text { minimum }\end{array}\right.$

Clevis well made?

Can adjustment of hitch in horizontal and vertical directions be easily made?

\section{Handles.}

Materials-wood or steel?

How connected to plow?

\section{Miscellaneous.}

Which of the middlebreakers studied do you prefer? 


\section{SUBSOIL PLOWS.}

\section{General Information.}

Exercise No. 4.

Trade name and number?

Manufacturer?

Address?

Size-width of shoe? inches; plowing depth?

Shoe.

Material-steel, cast iron or chilled cast iron?

How fastened to landbar?

Point reinforced?

Amount of vertical suction? -inch

Can suction be adjusted?

Landbar.

Heel reinforced?

Reinforcement removable?

\section{Standard.}

Material-steel or cast iron?

Is standard sharp?

\section{Beam.}

Material-wood or steel?

Height of hitch? $\left\{\begin{array}{l}\text { maximum } \\ \text { minimum }\end{array}\right.$

Clevis well made?

Can adjustment of hitch in horizontal and vertical directions be easily made?

Has plow gauge shoe or wheel?

\section{Handles.}

Material-wood or steel?

How connected to plow?

Can they be adjusted? 


\section{SUBSOIL PLOWS.}

General Information.

Exercise No. 4.

Trade name and number?

Manufacturex?

Address?

Size-width of shoe? inches; plowing depth? inches

Shoe.

Material-steel, cast iron or chilled cast iron?

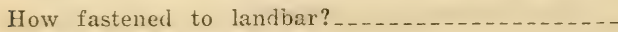

Point reinforced?

Amount of vertical suction? -inch

Can suction be adjusted?...........

\section{Landbar.}

Heel reinforced?

Reinforcement removable?

Standard.

Material-steel or cast iron?

Is standard sharp?

\section{Beam.}

Material-wood or steel?

Height of hitch? $\left\{\begin{array}{l}\text { maximum } \\ \text { minimum }\end{array}\right.$

Clevis well made?

Can adjustment of hitch in horizontal and vertical directions be easily made?

Has plow gauge shoe or wheel?

\section{Handles.}

Material-wood or steel?

How connected to plow?

Can they be adjusted?

\section{Miscellaneous.}

Do you understand how the plow is operated?....Which of the plows do you prefer? 


\section{SULKY AND GANG MOLDBOARD PLOWS.}

General Information.

Exercise No. 5.

Trade name and number?

Manufacturer?

Address?

How many bottoms?

Size of bottoms? -inches

\section{Moldboard.}

Material - steel, soft centered steel, ehilled cast iron?

Solid, slat or rod?

Type-stubble, sod or general purpose?

Which way is moldboard polished?

Is shin reinforced?

\section{Sharc.}

Point reinforced?

Bearing at wing? inch

How many bolts hold share on?

Amount of vertical suction? ..............inch

Amount of horizontal suction?

How can suction be varied?

\section{Landside.}

With or without landside?

Length? _inches

High, medium or low?

Frog.

Material-steel, cast iron or malleable?

Is it large or small?

\section{Beam.}

Frame or beam hitch?

Height of hitch? (plow bottom on floor) _......inches

Clevis well made? 
Frame. (Answer for frame plow).

Is frame strong and rigid enough to withstand the strains of plowing?

How many bails?

Are bearings of ample size?

Can they be easily removed?

How are the wheels attached to the frame?

Is the plow self leveling?

\section{Wheels.}

Wheels substantially attached to beam?

Rear furrow wheel set over from landside?_._.inch

Can this be adjusted?

All wheels adjustable?

Has rear wheel locking device?

Why are furrow wheels inclined?

Wheel boxes protected from dirt?

Easily oiled?

Removable hub bearings?

\section{Levers.}

How many hand levers?

How many foot levers?

Purpose of each?

Does spring aid in lifting plow?

Can plow be set to float?

Plow bottom will clear ground? inches

\section{Management of Plow.}

Tongue or tongueless?

How is plow guided?

Plow make as good corner to right as to left?

\section{Miscellaneous.}

Weed hooks?

Kind of coulters attached?

What adjustments are necessary to attach plow bottoms of different widths? 


\section{SULKY AND GANG MOLDBOARD PLOWS.}

\section{General Information.}

Exercise No. 5 .

Trade name and number?

Manufacturer?

Address?

How many bottoms?

Size of bottoms? inches

\section{Moldboard.}

Material-steel, soft centered steel, chilled cast iron?

Solid, slat or rod?

Type-stubble, sod or general purpose?

Which way is moláboard polished?

Is shin reinforced?

Share.

Point reinforced?

Bearing at wing? inch

How many bolts hold share on?

Amount of vertical suction?

Amount of horizontal suction? inch

How can suction be varied?

\section{Landside.}

With or without landside?

Length? inches

High, medium or low?

\section{Frog.}

Material-steel, cast iron or malleable?

Is it large or small?

\section{Beam.}

Frame or beam hitch?

Height of hitch? (plow bottom on floor) _..... inches Clevis well made? 
Frame. (Answer for frame plow).

Is frame strong and rigid enough to withstand the strains of plowing?

How many bails?

Are bearings of ample size?

Can they be easily removed?

How are the wheels attached to the frame?

Is the plow self leveling?

\section{Wheels.}

Wheels substantially attached to beam?

Rear furrow wheel set over from landside?_._.inches

Can this be adjusted?

All wheels adjustable?

Has rear wheel locking device?

Why are furrow wheels inclined?

Wheel boxes protected from dirt?

Easily oiled?

Removable hub bearings?

\section{Levers.}

How many hand levers? How many foot levers?

Purpose of each?

Does spring aid in lifting plow?

Can plow be set to float?

Plow bottom will clear ground? inches

\section{Management of Plow.}

Tongue or tongueless?

How is plow guidied?

Plow make as good corner to right as to left?

\section{Miscellaneous.}

Weed hooks?

Kind of coulters attached?

What adjustments are necessary to attach plow bottoms of different widths? 


\section{SULKY AND GANG MOLDBOARD PLOWS.}

\section{General Information.}

Exercise No. 5.

Trade name and number?

Manufacturer?

Address?

How many bottoms?

Size of bottoms? inches

\section{Moldboard.}

Material-steel, soft centered steel, chilled cast iron?

Solid, slat or rod?

Type-stubble, sod or general purpose?

Which way is moldboard polished?

Is shin reinforced?

\section{Share.}

Point reinforced?

Bearing at wing? inch

How many bolts hold share on?

Amount of vertical suction?

Amount of horizontal suction?

How can suction be varied?

\section{Landside.}

With or without landside?

Length? inches

High, medium or low?

\section{Frog.}

Material-steel, cast iron or malleable?

Is it large or small?

\section{Beam.}

Frame or beam hitch?

Height of hitch? (plow bottom on floor) _..._-inches Clevis well made? 
Frame. (Answer for frame plow).

Is frame strong and rigid enough to withstand the strains of plowing?

How many bails?

Are bearings of ample size?

Can they be easily removed?

How are the wheels attached to the frame?

Is the plow self leveling?

\section{Wheels.}

Wheels substantially attached to beam? Rear furrow wheel set over from landside?..._inches Can this be adjusted?

All wheels adjustable?

Has rear wheel locking device?

Why are furrow wheels inclined?

Wheel boxes protected from dirt?

Easily oiled?

\section{Levers.}

How many hand levers?

How many foot levers?

Purpose of each?

Does spring aid in lifting plow?

Can plow be set to float?

Plow bottom will clear ground? inches

\section{Management of Plow.}

Tongue or tongueless?

How is plow guided?

Plow make as good corner to right as to left?

\section{Miscellaneous.}

Weed hooks?

Kind of coulters attached?

What adjustments are necessary to attach plow bottoms of different widths? -

Which of plows studied do you prefer? 


\section{DISC PLOWS.}

General Information.

Exercise No. 6.

Trade name and number?

Manufacturer?

Address?

Discs.

Diameter? inches

How many?

How many bolts attach disc to casting?

Disc bearing dust proof?

Kind of bearing-plain, ball or roller?

How is bearing lubricated?

Dises easily removed for sharpening?

Scraper clean disc from center to edge?

Angle of disc adjustable?

May number of discs be increased or decreased?

Wheels.

How do wheels of this plow differ from those of other plows?

Which wheels are inclined?

Why are they inclined?

Wheel boxes protected from dirt?

How are wheels greased?

Can rear furrow wheel be locked?

Will rear furrow wheel castor in any direction?....-

Can rear furrow wheel be adjusted?

How is set of front furrow wheel controlled?

Which wheels are or can be weighted?

How can the rear furrow wheel be set to offset the pressure on disc?

Levers.

How many hand levers?

How many foot levers?

Purpose of each?

Are levers convenient to operator?

Disc will clear ground?._._._._._. inches.

How deep will disc plow?

Distance frame clears floor with disc on floor?..._...........inches

\section{Management of Plow.}

Reversible or non-reversible disc?

If reversible, how is it reversed?

How can width of cut be changed? 


\section{DISC PLOWS.}

\section{General Information.}

Trade name and number?........

Manufacturer?

Address?

\section{Discs.}

Diameter?

How many?

How many bolts attach disc to casting?

Dise bearing dust proof?

Kind of bearing-plain, ball or roller?

How is bearing lubricated?

Dises easily removed for sharpening?

Scraper clean dise from center to edge?

Angle of disc adjustable?

May number of dises be increased or decreased?

\section{Wheels.}

How do wheels of this plow differ from those of other plows?

Which wheels are inclined?

Why are they inclined?

Wheel boxes protected from dirt?

How are wheels greased?

Can rear furrow wheel be locked?

Will rear furrow wheel castor in any direction?.... Can rear furrow wheel be adjusted?

How is set of front furrow wheel controlled?......

Which wheels are or can be weighted?..........

How can the rear furrow wheel be set to offset the pressure on dise?

\section{Levers.}

How many hand levers?

How many foot levers?

Purpose of each?

Are levers convenient to operator?

Disc will clear ground?

How deep will disc plow? ........._....inches.

Distance frame clears floor with disc on floor?.... ............... inches

\section{Management of Plow.}

Reversible or non-reversible disc?

If reversible, how is it reversed?......

How can width of cut be changed?

\section{Miscellaneous.}

Which of the plows studied do you prefer? 


\section{ENGINE GANG MOLDBOARD PLOWS.}

\section{General Information.}

Exercise No. 7.

Trade name and number?

Manufacturer?

\section{Address?}

How many bottoms?

Size of bottoms? inches.

\section{Moldboard.}

Material-steel, soft centered steel, chilled cast iron?

Solid, slat or rod?

Type-stubble, sod ox general purpose?

Which way is moldboard polished?

Is shin reinforced?

\section{Share.}

Point reinforced?

Bearing at wing? inch.

How many bolts hold share on?

Amount of vertical suction?............

Amount of horizontal suction? inch.

How can suction be varied?

\section{Landside.}

Which bottoms have landsides?

Length? ........

High, medium or low?

Heel reinforced?

Reinforcement removable?

\section{Frog.}

Material-steel, cast iron or malleable?

Is it large or small? 


\section{Hitch.}

Frame or beam hitch?

Can hitch be adjusted vertically and horizontally?

Hitch have break pin or some other such device?...-

\section{Wheels.}

All wheels open?

Which wheels have traction lugs?

Wheel boxes protected from dirt?

How lubricated?

How many gauge wheels?

\section{Power Lift.}

Investigate lifting clutch and be prepared to explain. Which wheels furnish power for lifting?

Springs aid in lifting?

How high does plow share clear ground when lifted? inches.

\section{Levers.}

How many?

Purpose of each lever?

How many plow bottoms operated by one lever?

Can operator reach depth adjusting lever from seat of tractor?

Is position of levers satisfactory for orchard conditions?

\section{Miscellaneous.}

Kind of coulters used?

Any weed hooks?

Can plow be backed up? 


\section{ENGINE GANG MOLDBOARD PLOWS.}

\section{General Information.}

Exercise No. 7.

Trade name and number?

Manufacturer?

How many bottoms?

Size of bottoms? inches.

\section{Moldboard.}

Material—steel, soft centered steel, chilled cast iron?

Solid, slat or rod?

Type-stubble, sod or general purpose?

Which way is moldboard polished?

Is shin reinforced?

\section{Share.}

Point reinforced?

Bearing at wing? inch.

How many bolts hold share on?

Amount of vertical suction?

Amount of horizontal suction?

How can suction be varied?

\section{Landside.}

Which bottoms have landsides?

Length?

High, medium or low?

Heel reinforced?

Reinforcement removable?

Frog.

Material-steel, cast iron or malleable?

Is it large or small? 


\section{Hitch.}

Frame or beam hitch?

Can hitch be adjusted vertically and horizontally?

Hitch have break pin or some other such device?..--

\section{Wheels.}

All wheels open?

Which wheels have traction lugs?

Wheel boxes protected from dirt?

How lubricated?

How many gauge wheels?

\section{Power Lift.}

Investigate lifting clutch and be prepared to explain. Which wheels furnish powei for lifting? Springs aid in lifting?

How high does plow share clear ground when lifted? -inches.

\section{Levers.}

How many?

Purpose of each lever?

How many plow bottoms operated by one lever? Can operator reach depth adjusting lever from seat of tractor?

Is position of levers satisfactory for orchard conditions?

\section{Miscellaneous.}

Kind of coulters used?

Any weed hooks?

Can plow be backed up? 


\section{ENGINE GANG DISC PLOW.}

General Information.

Exercise No. 8.

Trade name and number?

Manufacturer?

Address?

\section{Discs.}

How many?

Diameter? inches.

How many bolts attach dise to casting?

Kind of bearing-plain, ball or roller?

Disc bearing dust proof?

Disc easily removed for sharpening?

Scraper clean disc from center to edge?

Scrapers adjustable?

Can angle of disc be changed?

\section{Wheels.}

How many?

Diameter of each?

Shape of rim?

Which are inclined?

Wheel boxes protected from dirt?

Easily lubricated?

Can extra weights be attached?

\section{Levers.}

How many hand levers?

Purpose of each?

Disc will clear ground? -inches.

How deep will dise plow? inches.

Is position of levers satisfactory for orchard conditions?

\section{Hitch.}

Height of hitch? inches.

Can hitch be adjusted vertically and horizontally?... -

Hitch have break pin or some other such device?...--

\section{Power Lift.}

Investigate lifting clutch and be prepared to explain.

Which wheels furnish power for lifting?

These wheels have lugs?

Springs aid in lifting? 


\section{ENGINE GANG DISC PLOW.}

General Information.

Exercise No. 8.

Trade name and number?

Manufacturer?

Address?

Discs.

How many?

Diameter? inches.

How many bolts attach disc to casting?

Disc bearing dust proof?

Kind of bearing-plain, ball or roller?

Disc easily removed for sharpening?

Scraper clean disc from center to edge?

Scrapers adjustable?

Can angle of disc be changed?

Wheels.

How many?

Diameter of each?

Shape of rim?

Which are inclined?

Wheel boxes protected from dirt?

Easily lubricated?

Can extra weights be attached?

\section{Levers.}

How many hand levers?

Purpose of each?

Disc will clear ground? inches.

How deep will disc plow?_._._._._. inches.

Is position of levers satisfactory for orchard conditions?

Hitch.

Height of hitch?

Can hitch be adjusted vertically and horizontally?..Hitch have break pin or some other such device?

\section{Power Lift.}

Investigate lifting elutch and be prepared to explain.

Which wheels furnish power for lifting?

These wheels have lugs?

Springs aid in lifting?

Miscellaneous.

Which of the plows studied do you prefer? 


\section{COULTERS AND JOINTERS.}

\section{Rolling Coulter.}

Exercise No. 9.

Manufacturer?

Address?

Diameter? inches.

Adjust rolling coulter to assigned plow for plowing 4 inches deep in stubble.

Same for plowing in stumpy land.

Instructor will check adjustment.

Note below how adjustments were made.

\section{Knife Coulter.}

Manufacturer?

Address?

Length of blade?

Adjustment for same conditions as for rolling coulter.

Note below how adjustments were made. 


\section{COULTERS AND JOINTERS.}

Fin Coulter.

Exercise No. 9.

Manufacturer?

Address?

To what part of plow is coulter attached?

\section{Jointer.}

Manufacturer?

Address?

Arljust jointer on assigned plow for plowing 6 inches deep.

Instructor will check adjustment.

Note below how adjustment was made.

\section{Combined Rolling Coulter and Jointer.}

Manufacturer?

Address?

Adjust for same conditions as did for jointer.

Note below how adjustment was made. 


\section{SPIKE TOOTH HARROW.}

General Information.

Exercise No. 10

Trade name and number?

Manufacturer?

Address?

How many sections?

\section{Teeth.}

Length? -inches.

Diameter? inch.

Shape-square, diamond, oval or round?

Can teeth be turned around when worn?

Have teeth heads?

Why are some teeth longer than others and have curved tops?

How are teeth fastened to frame?

Distance between teeth on bars? inches.

How many teeth per width of cut?

Fixed or adjustable?

\section{Frame.}

Flexible or rigid?

Will harrow adjust itself to uneven ground?

Material-wood or steel?

Frame well made and braced?

How many bars?

Distance between bars? inches.

Guards on ends of bars to protect against obstructions?

Connection to eveners-cast, malleable or forging?

Connections easily removed?

Frame strong enough to withstand twisting strains?

\section{Levers.}

How many per section?

Purpose of each?

Does tilting lever have spring?

What is purpose of spring?

Range of adjustment for teeth with tilting lever?

Can harrow be raised off the teeth for transporting?

\section{Miscellaneous.}

Can riding attachment be obtained for this harrow? 


\section{SPIKE TOOTH HARROW.}

General Information.

Exercise No. 10

Trade name and number?

Manufacturer?

Address?

How many sections?

Teeth.

Length? inches.

Diameter? inch.

Shape-square, diamond, oval or round?

Can teeth be turned around when worn?

Have teeth heads?

Why are some teeth longer than others and have curved tops?

How are teeth fastened to frame?

Distance between teeth on bars? inches.

How many teeth per width of cut?

Fixed or adjustable?

\section{Frame.}

Flexible or rigid?

Will harrow adjust itself to uneven ground?

Material-wood or steel?

Frame well made and braced?

How many bars?

Distance between bars? -inches.

Guards on ends of bars to protect against obstructions?

Connection to eveners-cast, malleable or forging?

Connections easily removed?

Frame strong enough to withstand twisting strains?

\section{Levers.}

How many per section?

Purpose of each?

Does tilting lever have spring?

What is purpose of spring?

Range of adjustment for teeth with tilting lever?

Can harrow be raised off the teeth for transporting?

\section{Miscellaneous.}

Can riding attachment be obtained for this harrow?

Which one of the harrows studied do you prefer? 


\section{STALK CUTTERS.}

\section{General Information.}

Excrcise No. 11.

Trade name and number?

Manufacturer?

Address?

Single or double?

\section{Cutter Head.}

How many knives?

Knives-straight or curved?

Knives-single or double edged?

Into what length will stalks be cut? inches

Material in spiders-cast or malleable?

Diameter of cutter head? inches.

Does shaft go clear through cutter head?

Is provision made to keep center of cutter head clear of stalks?

Bearings protected from dirt?

Bearings lubricated by grease or oil?

Bearings self aligning?

Will blades shear their bolts easily?

Frame.

Strong and well braced?

Spring hitch?

Hitch adjustable?

\section{Levers.}

How many?

Purpose of each?

How high can cutter be made to clear ground?..-inches.

Wheels.

Diameter?

Width tire?._._._._._._. inches.

Material-steel or cast iron?

Boxes protected from dirt?

How lubricated?

\section{Miscellaneous.}

Stalk hooks-how controlled?

Kind of seat spring?

Cutter convertible into cultivator? 


\section{STALK CUTTERS.}

General Information.

Exercise No. 11.

Trade name and number?

Manufacturer?

Address?

Single or double?

Cutter Head.

How many knives?

Knives-straight or curved?

Knives-single or double edged?

Into what length will stalks be cut?.........inches Material in spiders-cast or malleable?

Diameter of cutter head?............inches.

Does shaft go clear through cutter head?........

Is provision made to keep center of cutter head clear of stalks?

Bearings protected from dirt?

Bearings lubricated by grease or oil?

Bearings self aligning?

Will blades shear their bolts easily?

\section{Frame.}

Strong and well braced?

Spring hitch?

Hitch adjustable?

\section{Levers.}

How many?

Purpose of each?

How high can cutter be made to clear ground? inches.

\section{Wheels.}

Width tire? inches.

Diameter? inches.

Material-steel or cast iron?

Boxes protected from dirt?

How lubricated?

\section{Miscellaneous.}

Stalk hooks-how controlled?

Kind of seat spring?

Cutter convertible into cultivator?

Which of the stalk cutters do you prefer? 


\section{DISC HARROW.}

\section{General Information.}

Exercise No. 12.

Trade name and number?

Manufacturer?

Address?

Total cutting width? inches. Disc.

Diameter? inches.

How many?

Kind-full, cutaway or spading?

Distance between dises? _._._._._.

Cone shaped raised part in center of disc?

Amount of dish?

Which way does disc face: out or in?

\section{Bearings.}

How many?

Material-cast or malleable?

Bushings-wood, chilled iron or roller?

Thrust bearings?

Bearings easily lubricated?

Oil or grease used?

Bumpers used?

\section{Scrapers.}

Oscillating or stationary?

Can they be shifted to any part of disc?

Can they be locked off or on discs?

\section{Levers.}

How many hand?

How many foot?

Purpose of each?

Easy to operate from seat?

Size of angle that gangs make with tongue when they are in extreme position?

\section{Gangs.}

Gangs reversible?

Can gangs be separated?

How far apart? inches.

Can gangs be adjusted for ridges?

Gang bolt-round or square?

Gang bolt-diameter? inch.

Gang bolt locked in place?

\section{Frame.}

Type of steel bar used?

Riveted or bolted together?

Well trussed and braced?

Can rear gang be attached to the frame?............

How many standards?

Amount of clearance between discs and standards?

\section{Hitch.}

Stub or full tongue?

Tongue truck?

Can heighth of hitch be adjusted?

\section{Miscellaneous.}

Weight pans?

Method of transporting? 


\section{DISC HARROW.}

General Information.

Exercise No. 12.

Trade name and number? Manufacturer?

Address? Disc.

Total cutting width?_._._._._ft._._._._._inches.

Diameter? . . . . .

How many?

Kind-full, cutaway or spading?

Distance between discs? ............. inches.

Cone shaped raised part in center of disc? ....... Amount of dish?............... inch.

Which way does disc face: out or in?

\section{Bearings.}

How many?

Material-cast or malleable?

Bushings-wood, chilled iron or roller?

Thrust bearings?

Bearings easily lubricated?

Oil or grease used?

Bumpers used?

\section{Scrapers.}

Oscillating or stationary?

Can they be shifted to any part of disc?

Can they be locked off or on dises?

\section{Levers.}

How many hand?

How many foot?

Purpose of each?

Easy to operate from seat?

Size of angle that gangs make with tongue when they Gangs.

are in extreme position?

Gangs reversible?

Can gangs be separated?

How far apart? inches.

Can gangs be adjusted for ridges?

Gang bolt-round or square?

Gang bolt_-diameter?.............inch.

Gang bolt locked in place?

\section{Frame.}

Type of steel bar used?

Riveted or bolted together?

Well trussed and braced?

Can rear gang be attached to the frame?..........

How many standards?

Amount of clearance between dises and standards?

\section{Hitch.}

Stub or full tongue?

Tongue truck?

Can heighth of hitch be adjusted?

\section{Miscellaneous.}

Weight pans?

Method of transporting? 


\section{DISC HARROW.}

General Information.

Exercise No. 12.

Trade name and number?

Manufacturer?

Address?

Disc.

Total cutting width?

inches.

Diameter?

How many?

Kind-full, cutaway or spading?

Distance between discs? inches.

Cone shaped raised part in center of disc?

Amount of dish?

Which way does disc face: out or in?

\section{Bearings.}

How many?

Material-cast or malleable?

Bushings-wood, chilled iron or roller?

Thrust bearings?

Bearings easily lubricated?

Oil or grease used?

Bumpers used?

\section{Scrapers.}

Oscillating or stationary?

Can they be shifted to any part of disc?

\section{Levers.}

Can they be locked off or on dises?

How many hand?

How many foot?

Purpose of each?

Easy to operate from seat?

Size of angle that gangs make with tongue when they

\section{Gangs.}

are in extreme position?

Gangs reversible?

Can gangs be separated?

How far apart?

Can gangs be adjusted for ridges?

Gang bolt-round or square?

Gang bolt-diameter?............inch.

Gang bolt locked in place?

\section{Frame.}

Type of steel bar used?

Riveted or bolted together?

Well trussed and braced?

Can rear gang be attached to the frame?

How many standards?

Amount of clearance between discs and standards?

Hitch.

Stub or full tongue?

Tongue truck?

Can heighth of hitch be acijusted?

\section{Miscellaneous.}

Weight pans?

Method of transporting?

Which of the harrows studied do you prefer? 


\section{DOUBLE ACTING DISC HARROW.}

General Information.

Exercise No. 13.

Trade name and number? Manufacturer?

Address?

Total cutting width?

feet

inches

Disc.

How many in each gang?

How many gang's?

Kind-on front gangs, full or cutaway?

Kind-on rear gangs, full or cutaway?

Diameter?

Distance between dics? .

Amount of dish?........... inches.

Cone shaped raised part in center of disc?

Front gangs disc face in or out?

Rear gangs disc face in or out?

\section{Bearings.}

How many?

Material-cast or malleable?................

Bushings-wood, chilled iron or roller?

Bearings easily lubricated?

Thrust bearings?

Oil or grease used?

Bumpers used?

\section{Scrapers.}

Oscillating or stationary?

Can they be shifted to any part of the discs?

Can they be locked off or on dies?

\section{Gangs.}

Gangs reversible?

Can gangs be adjusted for ridges?

Gang bolt diameter? .............

Gang bolt locked in place?

\section{Levers.}

How many hand?

How many foot?

Purpose of each?

Easy to operate from seat?

Power angling device?

\section{Frame.}

Type of steel bar used?

Riveted or bolted together?

Well trussed and braced?

How many standards?

Amount of clearance between dises and standards? inches.

Examine flexibility of frame for turning.

How is rear section connected to front?.......

Can it be easily disconnected?

Hitch.

Tractor or team?

Stub or full tongue?

Tongue truck?

Can height of hitch be adjusted?

\section{Miscellaneous.}

Weight pans?

Method of transporting?
Can harrow be used for horses as well as tractor? 
DOUBLE ACTING DISC HARROW.

General Information.

Exercise No. 13.

Trade name and number?

Manufacturer?

Address?

Total cutting width?

Disc.

How many in each gang?

How many gangs?

Kind-on front gangs, full or cutaway?

Kind-on rear gangs, full or cutaway?

Diameter? -

Distance between dics?

Amount of dish?

Cone shaped raised part in center of disc?

Front gangs dise face in or out?

Rear gangs dise face in or out?

\section{Bearings.}

How many?

Material-cast or malleable?

Bushings-wood, chilled iron or roller?

Bearings easily lubricated?

Thrust bearings?

Oil or grease used?

Bumpers used?

\section{Scrapers.}

Oscillating or stationary?

Can they be shifted to any part of the dises?

Can they be locked off or on dics?

\section{Gangs.}

Gang's reversible?

Can gangs be adjusted for ridges?

Gang bolt diameter?

inch.

Gang bolt locked in place?

\section{Levers.}

How many hand?

How many foot?

Purpose of each?

Easy to operate from seat?

Frame.

Power angling device?

Type of steel bar used?

Riveted or bolted together?

Well trussed and braced?

How many standards?

Amount of clearance between dises and standards? inches.

Examine flexibility of frame for turning.

How is rear section connected to front?

Hitch.

Can it be easily disconnected?

Tractor or team?

Stub or full tongue?

Tongue truck?

Can height of hitch be adjusted?

\section{Miscellaneous.}

Weight pans?

Method of transporting?

Can harrow be used for horses as well as tractor?

Which of the harrows studied do youp prefer 
LAND ROLLERS AND PULVERIZERS.

\section{General Information.}

Exercise No. 14.

Trade name and number?

Manufacturer?

Address?

Width? feet.

Weight?

\section{Rollers.}

Diameter?._......... inches.

Width? .............. inches.

How many?

Shape rollers rim surface?

All roller's alike?

How many rollers to a gang?

How many gangs of rollers?

Will rollers adapt themselves to uneven ground?

\section{Frame.}

Material-wood or steel?

Corners reinforced?

Standards_cast iron or steel?

Bearings--east iron, wood or roller?

Easily lubricated?

Bearings constructed to exclude dirt?

Diameter of axle? .............. inches.

\section{Miscellaneous.}

Will this roller leave a mulch or smooth surface?

Does roller compact surface or sub-soil? 
LAND ROLLERS AND PULVERIZERS.

\section{General Information.}

Exercise No. 14.

Trade name and number?

Manufacturer?

Address?

Width? feet.

Weight?

\section{Rollers.}

Diameter? inches.

Width? inches.

How many?

Shape rollers rim surface?

All rollers alike?

How many rollers to a gang?

How many gangs of rollers?

Will rollers adapt themselves to uneven ground?.-.-.

\section{Frame.}

Material-wood or steel?

Corners reinforced?

Standards-cast iron or steel?

Bearings-cast iron, wood or roller?

Easily lubricated?

Bearings constructed to exclude dirt?

Diameter of axle?

\section{Miscellaneous.}

Will this roller leave a mulch or smooth surface?

Does roller compact surface or sub-soil?

Which of the rollers studied do you prefer? 
ONE ROW WALKING CORN PLANTER.

General Information.

Exercise No. 15.

Trade name and number?

Manufacturer?

Address?

\section{Seed Box.}

How many?

Kinds of seed can be sown?

Can two kinds of seed be sown at once?

What kinds?

Corn plates-edge selection or round hole?

Cotton seed sown in bunches or separately?

Is box hinged?

How is distance between seed varied?

How is seed plate driven?

\section{Furrow opener.}

Kind-stub, curved shoe or hoe?

How many valves in planter shank?

Depth gauge?

Can corn and soy beans be planted at the same time at different depths?

How many covering shovels?

What kind covering shovels?

\section{Frame.}

Well made and braced?

Handles adjustable?

\section{Wheels.}

Diameter press wheel?..........inches.

Does press wheel generate power?

How is planter thrown in and out of gear?

Is there a front wheel?

\section{Levers.}

How many?

Purpose of each?

Is the lever for throwing in and out of gear handy?

\section{Miscellaneous.}

Do the plates revolve when planter is in gear and backed?

Fertilizer attachment? 
ONE ROW. WALKING CORN PLANTER.

\section{General Information.}

Exercise No. 15.

Trade name and number?

Manufacturer?

Address?

\section{Seed Box.}

How many?

Kinds of seed can be sown?

Can two kinds of seed be sown at once?

What kinds?

Corn plates-edge selection or round hole?

Cotton seed sown in bunches or separately?

Is box hinged?

How is distance between seed varied?

How is seed plate driven?

\section{Furrow opener.}

Kind-stub, curved shoe or hoe?

How many valves in planter shank?

Depth gauge?

Can corn and soy beans be planted at the same time at different depths?

How many covering shovels?

What kind covering shovels?

\section{Frame.}

Well made and braced?

Handles adjustable?

\section{Wheels.}

Diameter press wheel?._._._._._inches.

Does press wheel generate power?

How is planter thrown in and out of gear?

Is there a front wheel?

\section{Levers.}

How many?

Purpose of each?

Is the lever for throwing in and out of gear handy?

\section{Miscellaneous.}

Do the plates revolve when planter is in gear and backed?

Fertilizer attachment? 


\section{ONE ROW WALKING CORN PLANTER.}

\section{General Information.}

Exercise No. 15.

Trade name and number?

Manufacturer?

Adress?

\section{Seed Box.}

How many?

Kinds of seed can be sown?

Can two kinds of seed be sown at once?

What kinds?

Corn plates-edge selection or round hole?

Cotton seed sown in bunches or separately?

Is box hinged?

How is distance between seed varied?

How is seed plate driven?

\section{Furrow opener.}

Kind-stub, curved shoe or hoe?

How many valves in planter shank?

Depth gauge?

Can corn and soy beans be planted at the same time at different depths?

How many covering shovels?

What kind covering shovels?

\section{Frame.}

Well made and braced?

Handles adjustable?

\section{Wheels.}

Diameter press wheel? inches.

Does press wheel generate power?

How is planter thrown in and out of gear?

Is there a front wheel?

\section{Levers.}

How many?

Purpose of each?

Is the lever for throwing in and out of gear handy?

\section{Miscellaneous.}

Do the plates revolve when planter is in gear and backed?

Fertilizer attachment?

Which of planters studied do you prefer? 
ONE ROW RIDING CORN PLANTER.

\section{General Information.}

Exercise No. 16.

Trade name and number?

Manufacturer?

Address?

\section{Seed Box.}

How many?

Kinds of seed can be sown?

Can two kinds of seed be sown at once?

What kinds?

Corn plates-edge selection or round hole?

Cotton seed sown in bunches or separately?

Is box hinged?

How is distance between seed varied?

How is seed plate driven?

\section{Furrow Opener.}

Kind-stub, curved shoe, hoe or sweep?

If sweep-what kind and size?

How many valves in planter shank?

Can corn and soy beans be planted at the same time, at different depths?

How many covering shovels?

What kind of covering shovels?

\section{Wheels.}

Diameter? feet.

Width of tire? inches.

Tires-flat or curved?

Cleaners?

Adjustable for different widths of track? Maximum ft. Minimum -ft.

One or both wheels supply power for planter operation?

\section{Levers.}

How many hand levers?

How many foot levers?

Purpose of each?

\section{Micellaneous.}

Fertilizer attachment?

Investigate how clutch works? 
ONE ROW RIDING CORN PLANTER.

General Information.

Exercise No. 15.

Trade name and number?

Manufacturer?

Address?

\section{Seed Box.}

How many?

Kinds of seed can be sown?

Can two kinds of seed be sown at once?

Corn plates-edge selection or round hole?

Cotton seed sown in bunches or separately?

What kinds?

Is box hinged?

How is distance between seed varied?

How is seed plate driven?

\section{Furrow Opener.}

Kind-stub, curved shoe, hoe or sweep?

If sweep-what kind and size?

How many valves in planter shank?

Can corn and soy beans be planted at the same time, at different depths?

How many covering shovels?

What kind of covering shovels?

\section{Wheels.}

Diameter? feet.

Width of tire?

Tires-flat or curved?

Cleaners?

Adjustable for different widths of track? Maximum ft. Minimum it.

One or both wheels supply power for planter operation?

\section{Levers.}

How many hand levers?

How many foot levers?

Purpose of each?

\section{Micellaneous.}

Fertilizer attachment?

Investigate how clutch works?

Which of planters studied do you prefer? 
TWO ROW CORN PLANTERS.

General Information.

Exercise No. 17.

Trade name and number?

Manufacturer?

Address?

\section{Seed Box.}

How many?

Kinds of seed sown?

Can two kinds of seed be sown at once?

What kinds?

Corn plates-edge selection or round hole?

Cotton seed sown in bunches or separately?

Are boxes hinged?

Can plates be changed without emptying seed box?

Seed-drilled, checked or both?

How is change made from one to the other?

Checked corn drop-cumulative or full hill?

Checked corn drop-continuous or intermittent?

How are seed plates driven?

How many speeds can plates be driven?

Can number of kernels dropped be changed without changing plates?

\section{Furrow Opener.}

Kind-stub, curved shoe, single or double disc?

Number of valves in planter shank?

Can corn and soy beans be planted at same time at different depths?

What effect does a short neck strap have on uniformity and depth of planting?

Maximum depth seed can be planted? inches. 


\section{Levers.}

How many hand levers?

How many foot levers?

Purpose of each?

\section{Checking Attachment.}

Vertical or horizontal checking bar?

How is reel attached and driven?

Can wire be released from the seat?

How far apart are the buttons on the wire? $f_{v}$ .......inches.

Can seed be dropped in hills without use of wire?

Can last two rows be sown and wire reeled up at the same time?

\section{Frame.}

Maximum width of rows? feet.

Minimum width of rows? feet.

Frame well made and braced?

\section{Wheels.}

Diameter? -inches.

Width? feet inches.

Kind-open, solid, concave, flat or double?

Cleaners?

Easily lubricated?

\section{Miscellaneous.}

What kind of marker?

How many?

Can it be easily raised, lowered and changed from one side to other?

Fertilizer attachment?

Can height of hitch be varied?

Investigate how clutch works.

Is drop shaft operated thru a clutch?

Is clutch on drop shaft or axle? 


\section{TWO ROW CORN PLANTERS.}

General Information.

Exercise No. 17.

Trade name and number?

Manufacturer?

Address?

\section{Seed Box.}

How many?

Kinds of seed sown?

Can two kinds of seed be sown at once?

What kinds?

Corn plates-edge selection or round hole?

Cotton seed sown in bunches or separately?

Are boxes hinged?

Can plates be changed without emptying seed box?

Seed-drilled, checked or both?

How is change made from one to the other?

Checked corn drop-cumulative or full hill?

Checked corn drop-continuous or intermittent?

How are seed plates driven?

How many speeds can plates be driven?

Can number of kernels dropped be changed without changing plates?

\section{Furrow Opener.}

Kind-stub, curved shoe, single or double disc?

Number of valves in planter shank?

Can corn and soy beans be planted at same time $x$ different depths?

What effect does a short neck strap have on uniformity and depth of planting?

Maximum depth seed can be planted? inches. 


\section{Levers.}

How many hand levers?

How many foot levers?

Purpose of each?

\section{Checking Attachment.}

Vertical or horizontal checking bar?

How is reel attached and driven?

Can wire be released from the seat?

How far apart are the buttons on the wire? ft. _........ inches.

Can seed be dropped in hills without use of wire?

Can last two rows be sown and wire reeled up at the same time?

\section{Frame.}

Maximum width of rows? feet.

Minimum width of rows? feet.

Frame well made and braced?

\section{Wheels.}

Diameter? feet inches.

Width? feet inches.

Kind-open, solid, concave, flat or double?

Cleaners?

Easily lubricated?

\section{Miscellaneous.}

What kind of marker?

How many?

Can it be easily raised, lowered and changed from one side to other?

Fertilizer attachment?

Can height of hitch be varied?

Investigate how clutch works.

Is drop shaft operated thru a clutch?

Is clutch on drop shaft or axle?

Which of planters studied do you prefer? 
General Information.

Trade name and number?

Manufacturer?

Address?

\section{Seed Box.}

Material-canvas, wood or steel?

Capacity bushels.

Seed dropped by knives, elevator or rotary table?

Can operator see seed dropping?

Seed liable to be damaged by dropping device?

How is distance between seed varied?

Can this change be easily and quickly made?

Agitator in bottom of box?

\section{Furrow Opener.}

Kind?

How is depth of planting adjusted?

Located directly under axle?

\section{Furrow Covers.}

Kind?

Adjustable for width, angle and depth?

Bearings easily oiled?

\section{Levers.}

How many?

Purpose of each?

Easily operated from seat?

\section{Wheels.}

Diameter? -inches.

Width of tire? feet

Bearingts protected from dirt?

Easily lubricated?

Power taken from one or both wheels?

Power transmitted by gears or chain?

\section{Miscellaneous.}

Number of men to operate?

Fertilizer attachment?

Where is fertilizer deposited with reference to tho seed?

What kind of marker?

Easily changed from side to side?

Adjustable as to length? 
General Information.

\section{POTATO PLANTER.}

Trade name and number?

Manufacturer?

Address?

\section{Seed Box.}

Exercise No. 18.

Material-canvas, wood or steel?

Capacity bushels.

Seed dropped by knives, elevator or rotary table?

Can operator see seed dropping?

Seed liable to be damaged by dropping device?.... How is distance between seed varied?

Can this change be easily and quickly made?

Agitator in bottom of box?

\section{Furrow Opener.}

Kind?

How is depth of planting adjusted?

Located directly under axle?

\section{Furrow Covers.}

Kind?

Adjustable for width, angle and depth?

\section{Levers.}

Bearings easily oiled?

How many?

Purpose of each?

Easily operated from seat?

\section{Wheels.}

Diameter? feet inches.

Width of tire? inches.

Bearings protected from dirt?

Easily lubricated?

Power taken from one or both wheels?

Power transmitted by gears or chain?

\section{Miscellaneous.}

Number of men to operate?

Fertilizer attachment?

Where is fertilizer deposited with reference to the seed?

What kind of marker?

Easily changed from side to side?

Adjustable as to length?

Which of the planters studied do you prefer? 
Wheelbarrow.

BROADCASTERS.

Trade name and number?

Exercise No. 19.

Manufacturer?

Address?

Seed box \{ $\begin{aligned} & \text { width? } \\ & \text { length? }\end{aligned}$

Capacity of seed box? pecks.

Investigate how power is generated and applied?

How is amount of seed sown adjusted?

Kinds of seed can be sown?

Knapsack Seeder.

Trade name and number?

Manufacturer?

Address?

Capacity of bag? pecks.

Investigate how power is generated and applied?

How is amount of seed sown adjusted?

Kinds of seed sown?

\section{Endgate Seeder.}

Trade name and number?

Manufacturer?

Address?

Capacity of seed box? pecks.

Investigate how power is generated and applied?

How is amount of seed sown adjusted?........

Number of scattering fans?

Force feed?

Agitator?

Grass seed attachment?

Two-Wheel Seeder.

Trade name and number?

Manufacturer?

Address?

Seed box \{lepth? $\begin{aligned} & \text { width? } \\ & \text { length? }\end{aligned}$

Capacity of seed box?

Investigate how power is generated and applied.

How is amount of seed sown adjusted?

Force feed?

Agitator?

Grass seed attachment? 


\section{General Information.}

Trade name and number?

Manufacturer?

Address?

Size? ffurrow openers distance apart.

\section{Seed Box.}

Cubical contents? cubic inches.

Shape of end?

Trussed?

Metal or wood bottom?

Covers-one or two pieces?

Agitator?

Grass seed attachment?

Fertilizer attachment?

Will all seed go into seed cups when box is about empty?

\section{Valves.}

Seed shaft driven by chain or shaft drive?

Feed regulated by speed of shaft or exposure of seed shell?

Kinds of seed can be sown?

\section{Seed Tubes.}

Material-rubber, wire or spiral spring?

\section{Furrow Opener.}

Kind-hoe, shoe, single or double disc?

Staggard or in line?

Can spacing be varied?

Can suction be varied?

Are they in front, behind or under main axle?

How are they forced in ground?

Disc bearing easily lubricated?

Disc bearing large enough to cause clogging?

Does disc form one side of boot?

Kind of disc bearing?

\section{Frame.}

Well braced and balanced?...................

Reinforced corners?

Single or double draw bars for furrow openers?

Main axle bearings-plain, roller or self aligning?

Are bearings easily oiled?

\section{Levers.}

How many?

Purpose of each?

Does lifting furrow openers throw machine out of gear?

Power lift?

\section{Wheels.}

Wood or steel?

Diameter?

Width?

feet inches.

\section{Miscellaneous.}

Covering chains or press wheels?

Seat or foot board?

Land measure provided?

Can it be adjusted? 
General Information.

GRAIN DRILLS.

Trade name and number?

Exercise No. 20.

Manufacturer?

Address?

Size?

Seed Box.

Cubical contents?

Shape of end?

Trussed?

Metal or wood bottom?

Covers-one or two pieces?

Agitator?

Grass seed attachment?

Fertilizer attachment?

Will all seed go into seed cups when box is about empty?

\section{Valves.}

Seed shaft driven by chain or shaft drive?

Feed regulated by speed of shaft or exposure of seed shell?

Kinds of sced can be sown?

\section{Seed Tubes.}

Material-rubber, wire or spiral spring?

\section{Furrow Opener.}

Kind-hoe, shoe, single or double disc?

Staggard or in line?

Can spacing be varied?

Can suction be varied?

Are they in front, behind or under main axle?

How are they forced in ground?

Disc bearing easily lubricated?

Disc bearing large enough to cause clogging?

Does dise form one side of boot?

Kind of disc bearing?

\section{Frame.}

Well braced and balanced?

Reinforced corners?

Single or double draw bars for furrow openers?

Main axle bearings-plain, roller or self aligning?

Are bearings easily oiled?

\section{Levers.}

How many?

Purpose of each?

Does lifting furrow openers throw machine out of gear?

Power lift?

\section{Wheels.}

Wood or steel?

Diameter?_........... feet_..._._._._. inches.

Width?

\section{Miscellaneous.}

Covering chains or press wheels?

Seat or foot board?

Land measure provided?

Can it be adjusted?

Which of grain drills studied do you prefer? 
TWO WHEEL CULTIVATOR.

General Information.

Exercise No. 21.

Trade name and number?

Manufacturer?

Address?

Single or double row?

Riding, walking or combined?

Shovels.

How many to gang?

Width? inches.

Spring trip or break pin?

Shovel adjustable?

Are shanks attached rigidly to beam or are they adjustable?

Spring tooth attachment?

Dise attachment?

Shields.

Kind-sheet, rod or revolving?

Adjustable?

Gangs or Rigs.

Method of guiding gangs-foot, pivotal wheel or se:at shift?

Gangs remain horizontal when moved right or left?

Can gangs be moved independent of one another?

Connection to frame flexible?

Connection adjustable for wear?

Spreading arch?

Frame.

Can distance between gangs be quickly changed?

How is framed balanced?

Is frame automatically balanced when gangs are raised or lowered?

Seat-kind?

Corn can be cultivated to the height of? _._. inches.

Wheels.

Diameter?

feet inches

Width? inches.

Tire flat or concave?

Diameter axle?................ inches.

Expanding axle?

Close as wheels can be put together? feet.

Widest wheels can be separated?._._._._..... feet.

Wheel boxes protected against dirt?

Levers.

How many?

Purpose of each?

Does spring aid in lifting gangs?

Can spring be regulated?

Are levers easily operated from seat?

Can the gangs be lifted out of ground without disturbing levers that control depth of shovels?

Miscellaneous.

Pivotal wheel?

Height of hitch adjustable? 


\section{TWO WHEEL CULTIVATOR.}

\section{General Information.}

Exercise No. 21.

Trade name and number?

Manufacturer?

Address?

Single or double row?

Riding, walking or combined?

\section{Shovels.}

How many to gang?

Width? -inches.

Spring trip or break pin?

Shovel adjustable?

Are shanks attached rigidly to beam or are they adjustable?

Spring tooth attachment?

Disc attachment?

\section{Shields.}

Kind-sheet, rod or revolving?

Adjustable?

\section{Gangs or Rigs.}

Method of guiding gangs-foot, pivotal wheel or seat shift?

Gangs remain horizontal when moved right or left?

Can gangs be moved independent of one another?

Connection to frame flexible?

Connection adjustable for wear?

Spreading arch?

Can distance between gangs be quickly changed? $\ldots$

\section{Frame.}

How is framed balanced?

Is frame automatically balanced when gangs are raised or lowered?

Seat-kind?

Corn can be cultivated to the height of? inches.

\section{Wheels.}

Diameter?

feet inches

Width? inches.

Tire flat or concave?

Diameter axle? inches.

Expanding axle?

Close as wheels can be put together?._._._._._feet. Widest wheels can be separated?..._......_._. feet. Wheel boxes protected against dirt?

\section{Levers.}

How many?

Purpose of each?

Does spring aid in lifting gangs?

Can spring be regulated?

Are levers easily operated from seat?

Can the gangs be lifted out of ground without disturbing levers that control depth of shovels?

\section{Miscellaneous.}

Pivotal wheel?

Height of hitch adjustable? 


\section{TWO WHEEL CULTIVATOR.}

General Information.

Exercise No. 21.

Trade name and number?

Manufacturer?

Address?

Single or double row?

Riding, walking or combined?

\section{Shovels.}

How many to gang?

Width? inches.

Spring trip or break pin?

Shovel adjustable?

Are shanks attached rigidly to beam or are they adjustable?

Spring tooth attachment?

Dise attachment?

\section{Shields.}

Kind-sheet, rod or revolving?

Adjustable?

\section{Gangs or Rigs.}

Method of guiding gangs-foot, pivotal wheel or seat shift?

Gangs remain horizontal when moved right or left?

Can gangs be moved independent of one another?

Connection to frame flexible?

Connection adjustable for wear?

Spreading arch?

Can distance between gangs be quickly changed?...-

\section{Frame.}

How is framed balanced?

Is frame automatically balanced when gangs are raised or lowered?

Seat-kind?

Corn can be cultivated to the height of?._-_-_inches. Wheels.

Diameter? -inches

Width? feet -inches.

Tire flat or concave?

Diameter axle?.......

Expanding axle?

Close as wheels can be put together? feet.

Widest wheels can be separated?_._._._._._. feet.

Wheel boxes protected against dirt?

\section{Levers.}

How many?

Purpose of each?

Does spring aid in lifting gangs?

Can spring be regulated?

Are levers easily operated from seat?

Can the gangs be lifted out of ground without disturbing levers that control depth of shovels?

\section{Miscellaneous.}

Pivotal wheel?

Height of hitch adjustable?

Which of cultivators studied do you prefer? 
MOWER.

General Information.

Exercise No. 22.

Trade name and number?

\section{Manufacturer?}

Address?

Size or width of cut? feet.

Vertical, or plain lift type?

\section{Cutter Bar.}

Ledger plates-smooth or serrated?

How many wearing plates?

Length of wearing plates? inches.

Can bar be adjusted for both alignment and registration?

Bar reinforced?

Bar tempered?

Bar curved up or down for any reason?

How much will outer end of bar drop below wheel base level? -inches.

How high can bar be raised by adjusting shoes?..... inches.

Is weight of bar carried on frame?

Are guards strong enough to stay in alignment?...

\section{Sickle.}

How many sections?

Knife head-steel drop forging or malleable?

How far do sections project over wearing plates? -inches.

\section{Pitman.}

Material-wood or steel?

Length? inches.

Method of lubricating crank end?

Bearing at crank end-iron, babbitt or bronze?

Can bearing be removed?

Connection at sickle end-malleable or hardened steel?

This connection have automatic take up for wear?.--

\section{Wheels.}

Width of track, center to center? inches

Diameter? feet inches.

Width of tire? inches.

Rachets on inner or outer sides of wheels?

Pawls-loose or fastened in place? 


\section{Levers.}

How many hand levers?

How many foot levers?

Purpose of each?

Is clutch lever so constructed as to be operated quickly with the foot?

With the operator in the seat, can bar be folded vertically or semi-vertical?

Which end of the bar picks up first when foot lever is raised?

Distance mower will travel after clutch is thrown in before sickle starts? inches.

When the tilting lever is moved from the first to the last notch, is the outer end of the cutter bar moved in a horizontal direction without the inner end being moved a like amount?

Levers. (Vertical Lift).

Does clutch move when foot lifting lever is used?...-

Is clutch out when hand lifting lever is in front notch?

How high is outer edge of bar off ground when machine goes automatically out of gear?

Levers. (Plain Lift).

Height of inside shoe from ground when the lifting lever is in the extreme rear position and knife running?

Maximum angle between sickle and pitman in normal position?

Maximum angle between sickle and pitman when bar

\section{Gearing.} is suspended in extreme high position?

Main gear-internal or external?

Is gearing well protected from dirt, trash and accidents?

Easily lubricated?

Can wear in bevel gears be adjusted?

Ball bearing to take end thrust of bevel gre?

Variable speed?

How is speed varied?

Revolutions of fly wheel per 100 inches of travel?

Direction of rotation of fly wheel looling from driv er's seat?

\section{Miscellaneous.}

Main axle have roller bearings?

What is the highest obstruction mower will clear?

With

With operator in seat, bar on ground, neckyoke on tongue, determine with spring balances amount of weight at point where neckyoke is attached to tongue?

Same with bar off ground?

How many oil holes on machine?

How many grease cups on machine?

Note:-For all these tests with the mower front end of the tongue 32 inches mower have the ground line, unless otherwise noted on mower tongue. 
Trade name and number?

Manufacturer?

Address?

Size or width of cut? feet.

Vertical, or plain lift type?

\section{Cutter Bar.}

Ledger plates-smooth or serrated?

How many wearing plates?

Length of wearing plates? -inches.

Can bar be adjusted for both alignment and registration?

Bar reinforced?

Bar tempered?

Bar curved up or down for any reason?

How much will outer end of bar drop below wheel base level? inches.

How high can bar be raised by adjusting shoes?....inches.

Is weight of bar carried on frame?

Are guards strong enough to stay in alignment?...-

\section{Sickle.}

How many sections?

Knife head-steel drop forging or malleable?

How far do sections project over wearing plates? inches.

\section{Pitman.}

Material-wood or steel?

Length? inches.

Method of lubricating crank end?

Bearing at crank end-iron, babbitt or bronze?

Can bearing be removed?

Connection at sickle end-malleable or hardened steel?

This connection have automatic take up for wear?.--

\section{Wheels.}

Width of track, center to center?_.._ft._._. inches Diameter? feet -inches.

Width of tire? inches.

Rachets on inner or outer sides of wheels?

Pawls-loose or fastened in place? 
Levers.

How many hand levers?

How many foot levers?

Purpose of each?

Is clutch lever so constructed as to be operated quickly with the foot?

With the operator in the seat, can bar be folded vertically or semi-vertical?

Which end of the bar picks up first when foot lever is raised?

Distance mower will travel after clutch is thrown in before sickle starts? inches.

When the tilting lever is moved from the first to the last notch, is the outer end of the cutter bar moved in a horizontal direction without the inner end being moved a like amount?

Levers. (Vertical Lift).

Does clutch move when foot lifting lever is used?....

Is clutch out when hand lifting lever is in front notch?

How high is outer edge of bar off ground when machine goes automatically out of gear?

Levers. (Plain Lift).

Height of inside shoe from ground when the lifting lever is in the extreme rear position and knife
running?

Maxmum angle between sickle and pitman in nor mal position?

Maximum angle between sickle and pitman when bav

Gearing. is suspended in extreme high position?

Main gear-internal or external?

Is gearing well protected from dirt, trash and ac-

Easily lubricated?

Can wear in bevel groars be adjuste

Ball bearing to adjusted?

Variable speed?

How is speed varied?

Direction of fly wheel per 100 inches of travel? er's seat?

\section{Miscellaneous.}

Main axle have roller bearings?

What is the highest obstruction

...-inches.

mower will clear?

operator in seat, bar on grount

tongur on ground, neckyoke on of determine with spring balances amount

to tongue? .

How many oil hround?........... lbs.

How many greases on machine?

Note-For all these cups on machine?

front end of the tonts with the mower have the ground line, unless othe 32 inches from center to the 


\section{MOWER.}

\section{General Information.}

Exercise No. 22.

Trade name and number?

Manufacturer?

Address?

Size or width of cut?

feet.

Vertical, or plain lift type?

\section{Cutter Bar.}

Ledger plates-smooth or serrated?

How many wearing plates?

Length of wearing plates -inches.

Can bar be adjusted for both alignment and registration?

Bar reinforced?

Bar tempered?

Bar curved up or down for any reason?

How much will outer end of bar drop below wheel base level? inches.

How high can bar be raised by adjusting shoes?...-inches.

Is weight of bar carried on frame?

Are guards strong enough to stay in alignment?...-

\section{Sickle.}

How many sections?

Knife head-steel drop forging or malleable?

How far do sections project over wearing plates? inches.

\section{Pitman.}

Material-wood or steel?

Length? inches.

Method of lubricating crank end?

Bearing at crank end-iron, babbitt or bronze?

Can bearing be removed?

Connection at sickle end-malleable or hardened steel?

This connection have automatic take up for wear? ---

\section{Wheels.}

Width of track, center to center?_._-_ft.____inches Diameter?_._._._._. feet__._._._._. inches.

Width of tire?

Ratchets on inner or outer sides of wheels?

Pawls-loose or fastened in place? 


\section{Levers.}

How many hand lever's?

How many foot levers?

Purpose of each?

Is clutch lever so constructed as to be operated quickly with the foot?

With the operator in the seat, can bar be folded vertically or semi-vertical?

Which end of the bar picks up first when foot lever is raised?

Distance mower will travel after clutch is thrown in before sickle starts?

When the tilting lever is moved from the first to the last notch, is the outer end of the cutter bar moved in a horizontal direction without the inner end being moved a like amount?

Levers. (Vertical Lift).

Does clutch move when foo: lifting lever is used?

Is clutch out when hand lifting lever is in frout noteh?

How high is outer edge of bar off rround when machine goes automatically out of gear?

Levers. (Plain Lift).

Height of inside shoe from ground when the lifting lever is in the extreme rear position and knife running?

Maxmum angle between sickle and pitman in normal position?

Maximum angle between sickle and pitman when bar

\section{Gearing.} is suspended in extreme high position?

Main gear-internal or external? Is gearing well protected from dirt, trash and ac-
cidents?

Easily lubricated?

Can wear in bevel gears be adjusted?

Ball bearing to take end thrust of bevel gaar?

Variable sneed?

How is speed varied?

Revolutions of fly wheel per 100 inthes of tiravel?

per 100 inches of travel? er's seat?

\section{Miscellaneous.}

Main axle have roller bearings?

What is the highest obstruction mower will clear?

With opesator.

tongue, determeat, bar on ground, neckyoke on of weighetermine with spring balances amount to tongue?

Same with bar off ground? Ibs.

How many oil holes on machine?

How many grease cups on machine?

Which of the mowers studied do you prefer?

Note:-For all these tests with the front end of the tongue 32 mower have the ground line, unless otherwise noted on mower tongue. 


\section{SIDE DELIVERY HAY RAKE. \\ General Information. \\ Exercise No. 23.}

Trade name and number?

Manufacturer?

Address?

Kind-reel or fork type?

Width swath raked?._._._.... feet.

\section{Reel Type.}

Reel material-wood or steel?

Length reel?..._. feet.

How many bars?

How many teeth on each bar?

Curved or straight teeth?

Can setting of teeth be varied?

Power transmitted to reel by gearing or chains?

How many stripper bars?

Are they round, flat or oval?

Are they rigid?

Teeth conform to uneven ground?

Bearings, plain or rollex?

Bearings easily lubricated?

Fork Type.

Diameter crank shaft?

How many forks?

How many teeth to each fork?

Will forks adjust themselves to uneven ground?

Bearings, plain or roller?

Bearings easily lubricated?

Power transmitted to forks by gearing or chain?

\section{Frame.}

Material-wood or steel?

Well braced?

Corners reinforced?

\section{Main Wheels.}

How many?

Diameter feet inches.

Width?

Easily lubricated?

Bearings, plain or roller?

Lugs on wheels?

\section{Caster Wheels.}

How many?

Diameter?

Width? inches.

Can they be adjusted? - feet inches.

Shields to prevent wrapping when tedding?

Bearings-plain or rollex?

Easily lubricated?

\section{Levers.}

How many?

Purpose of each?
Can it be thrown out of gear while rake is moving?

Can it be reversed and made to do work of tedder?

Can levers be operated from seat? 


\section{SIDE DELIVERY HAY RAKE.}

General Information.

Exercise No. 23.

Trade name and number?

Manufacturer?

Address?

Kind-reel or fork type?

Width swath raked?.......... feet.

\section{Reel Type.}

Reel material-wood or steel?

Length reel? feet.

How many bars?

How many teeth on each bar?

Curved or straight teeth?

Can setting of teeth be varied?

Power transmitted to reel by gearing or chains?

How many stripper bars?

Are they round, flat or oval?

Are they rigid?

Teeth conform to uneven ground?

Bearings, plain or roller?

Bearings easily lubricated?

\section{Fork Type.}

Diameter crank shaft?...............inches.

How many forks?

How many teeth to each fork?

Will forks adjust themselves to uneven ground? _..Bearings, plain or roller?

Bearings easily lubricated?

Power transmitted to forks by gearing or chain?

\section{Frame.}

Material-wood or steel?

Well braced?

Corners reinforced?

\section{Main Wheels.}

How many?

Diameter.

Width? feet

Easily lubricated?

Bearings, plain or roller?

Lugs on wheels?

\section{Caster Wheels.}

How many?

Diameter?

Width? feet inches.

Can they be adjusted? feet.

Shields to prevent wrapping when tedding? Bearings-plain or roller?

Easily lubricated?

\section{Levers.}

How many?

Purpose of each?

Can it be thrown out of gear while rake is moving?

Can it be reversed and made to do work of tedder?

Can levers be operated from seat?

\section{Miscellaneous.}

Which rake studied do you prefer? 


\section{HAY LOADERS.}

General Information.

Exercise No. 24.

Trade name and number?

Manufacturer?

Address?

Kind-rake or cylinder type?

Width it talies hay?............... feet.

\section{Elevator.}

Maximum height elevator will put hay?......... feet.

Width at top?

Wheels.

How many?

Easily lubricated?

Bearings-plain or roller ?

Hiteh.

What type of lugs on wheels?

How coupled to wagon?

Can it be uncoupled from top of load?

Fore carriage or stiff tongue?

\section{Cylinder Type.}

One or two cylinder's?

Rear cylinder hinged or rigid?

If hinged, is it snring adjusted?

Cylinder material-wood or steel?

Diameter of cylinder?..._......feet.

How many rows of teeth?

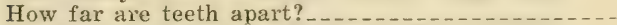

Teeth adjust themselves to ground?

What prevents hay from following cylinder clear around?

Is there anything to prevent hay from following endless apron down between wagon and loader?

Frame material-wood or steel?

Chain or gear drive?

Distance passed over per revolution of cylinder?.... .

\section{Rake Type.}

How many bars with rakes?

How many rakes to bar?

Bars material-wood or steel?

Investigate method used to give motion to bar's?...-

Ground rakes adjust themselves to ground conditions?

Ground rakes drag or lift hay?

Can each rake bar independent of other's adjust itself. to uneven ground?

Crank shaft diameter?

Bearings easily lubricated?

What prevents hay from falling between wagon and loader?

Chain, gear or gearless drive?

Distance passed over per stroke of each group of bars? feet

Maximum opening from lower edge of the inclined deck to ground?......_feet. Min._....._feet.

Ground wheels set under loader far enough to allow machine to go close to fences and ditches?.....

\section{Miscellaneous.}

How many roller bearings on machine? 
HAY LOADERS.

General Information.

Trade name and number?

Manufacturer?

Address?

Kind-rake or cylinder type?

Width it takes hay? feet.

\section{Elevator.}

Maximum height elevator will put hay?_._._._. feet.

Wiclth at top?

\section{wheels.}

How many?

Easily lubricated?

Bearings-plain or roller ?

What type of lugs on wheels?

\section{Hitch.}

How coupled to wagon?

Can it be uncoupled from top of load?

Fore carriage or stiff tongue?

\section{Cylinder Type.}

One or two cylinders?

Rear cylinder hinged or rigid?

If hinged, is it spring adjusted?

Cylinder material-wood or steel?

Diameter of cylinder?........._feet.

How many rows of teeth?

How far are teeth anart?

Teeth adjust themselves to ground?

What prevents hay from following cylinder clear around?

Is there anything to prevent hay from following endless apron down between wagon and loader?....-

Frame material-wood or steel?

Chain or gear drive?

Distance passed over per revolution of cylinder.... -

\section{Rake Type.}

How many bars with rahes? ..................

How many rakes to bar?

Bars material-wood or steel?

Investigate method used to give motion to bars?

Ground rakes adjust themselves to ground conditions?

Ground rakes drag or lift hay?

Can each rake bar independent of others adjust itself to uneven ground?

Crank shaft diameter?

Bearings easily lubricated?

What prevents hay from falling between wagon and loader?

Chain, gear or gearless drive?

Distance passed over per stroke of each group of bar's? _.

Maximum opening from lower edge of the inclined deck to ground?...... feet. Min._._._._feet.

Ground wheels set under loader far enough to allow machine to go close to fences and ditches?

\section{Miscellaneous.}

How many roller bearings on machine?

Which of loaders studied do you prefer? 
GRAIN BINDERS.

General Information.

Exercise No. 25 .

Trade name and number? .................... Manufacturer?

Adidress?

Width of cut? feet.

Right or left hand?

Main Wheel.

Diameter? inches.

Width of tire?..............

Bearings-plain, ball or roller?

\section{Grain Wheel.}

Diameter? ................ feet.

Width tire? ................. inches.

Bearings-plain, ball or roller?

Easily lubricated?

Bottom of wheel inside of point of outside divider? inches.

\section{Main Drive Chain.}

Width of links? inches.

Links steel or malleable?

Links with or without pins?

How is chain tightened?

\section{Counter Shaft.}

Bearings-plain, ball or roller,-self aligning?

Can bearings be adjusted for wear?...............

Can shaft be adjusted to give proper mesh to gears"?

\section{Crank Shaft.}

Bearings-plain, ball or roller,-self aligning?

Investigate operation of clutch?

\section{Sickle.}

How many sections?

How is pitman connected to sickle?

Sections-plain or serrated?

Is sickle head protected?

Revolutions of crank shaft to 100 inches travel of machine?

Direction of rotation of fly wheel looking from driver's seat?

\section{Cutter Bar.}

Ledger plates-smooth or serrated?

Separate wearing plates?

Clips-nalleable or steel?

\section{Pitman.}

Material-wood or steel?

Easily removed if broken?

Bearings at crank easily lubricated?............. Bearing bushing at crank end-iron, babbitt $0 \mathrm{r}^{*}$ bronze?

\section{Bevel Gear.}

How many on machine?

Can they be adjusted for wear?

Are they protected? 


\section{Elevators.}

Open or closed type?

Does loose or tight side of canvases run next to grain?

How are elevators squared up?

Distance grain is elevated above platform bottom? feet.

Can canvas be loosened or tightened by any other means than straps?

Travel of elevator apron per 100 inches travel of machine? inches.

Travel of platform apron per 100 inches travel of machine? inches.

\section{Binder Attachment.}

Twine tension kind?

How many packers?

How many discharge arms?

Has needle a stecl roller in eye?

Kind of butter-canvas, wood or steel?

Twine box handy to seat?

Determine how to thread machine and tie knot.

How are size and tightness of bundles regulated?

\section{Transporting Attachment.}

Extra wheels easily removed and replaced?.......

Tongue easily adjusted?

Can inside and outside grain divide be adjusted?....

How narrow and low a place can be gone thru?

Reel.

$$
\text { Width?.......feet. Height?........feet. }
$$

How far in front of sickle can it be adjusted?_._feet.

How near ground can it be lowered?

How many slats?

Can reel be folded back:?

Outer end supported?

How many spiders?

Travel of reel slat per 100 inches travel of machine? inches.

How is reel driven-chain or gear?

\section{Bundle Carriers.}

Unloads by tipping or swinging?

If it hits an obstacle will it move out of way? .......

Will it scatter the bundles?

Does carrier raise from stubble before swinging into position?

\section{Levers.}

How many hand levers?

How many foot levers?

Purpose of each?

\section{Frame.}

Can they be easily operated from seat?

Form of steel used, angle, I beam, channel or square steel tube?

Do you consider frame strong and well balanced?...

\section{Miscellaneous.}

Has binder a tongue truck? 


\section{GRAIN BINDERS.}

General Information.

Trade name and number?.................

Manufacturer?

Adidress?

Width of cut?

feet.

Right or left hand?

Main Wheel.

Diameter? inches.

Width of tire? feet inches.

Bearings-plain, ball or roller?

\section{Grain Wheel.}

Diameter?

Width tire? inches.

Bearings-plain, ball or roller?

Easily lubricated?

Bottom of wheel inside of point of outside divider? -inches.

\section{Main Drive Chain.}

Width of links? inches.

Links steel or malleable?

Links with or without pins?

How is chain tightened?

\section{Counter Shaft.}

Bearings-plain, ball or roller,-self aligning?

Can bearings be adjusted for wear?

Can shaft be adjusted to give proper mesh to gears?

\section{Crank Shaft.}

Bearings-plain, ball or roller,-self aligning?

Investigate operation of clutch? Sickle.

How many sections?

How is pitman connected to sickle?

Sections-plain or serrated?

Is sickle head protected?

Revolutions of crank shaft to 100 inches travel of machine?

Direction of rotation of fly wheel looking from driver's seat?

\section{Cutter Bar.}

Ledger plates-smooth or serrated?

Separate wearing plates?-

Clips-malleable or steel?

\section{Pitman.}

Material-wood or steel?

Easily removed if broken?

Bearings at crank easily Jubricated? _.........

Bearing bushing at crank end-iron, babbitt $x$ bronze?

\section{Bevel Gear.}

How many on machine?

Can they be adjusted for wear?

Are they protected? 


\section{Elevators.}

Open or closed type?

Does loose or tight side of canvases run next to grain?

How are elevator's squared up?

Distance grain is clevates? above platform bottom? feet.

Can canvas be loosened or tightened by any othar means than straps?

Travel of elevator apron per 100 inches travel of machine? inches.

Travel of platform apron per 100 inches travel of machine? inches.

\section{Binder Attachment.}

Twine tension kind?

How many packers?

How many discharge arms?

Has needle a steel roller in eye?

Kind of butter-canvas, wood or steel.

Twine box handy to seat?

Determine how to thread machine and tie knot.

How are size and tightness of bundles regulated?

\section{Transporting Attachment.}

Extra wheels easily removed and replaced?

Tongue easily adjusted?

Can inside and outside main divide be adjusted?

How narrow and low a place can be gone thru?

\section{Reel.}

$$
\text { Width?.......feet. Height?....... feet. }
$$

How far in front of sickle can it be adjusted? ... feet.

How near ground can it be lowered?

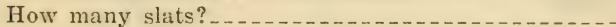

Can reel be folded back?

Outer end supported?

How many spiders?

Travel of reel slat per 100 inches travel of machine?

How is reel driven-chain or gear?

\section{Bundle Carriers.}

Unloads by tipping or swinging?

If it hits an obstacle will it move out of way? ......

Will it seatter the bundles?

Does carrier raise from stubble before swinging into position?

\section{Levers.}

How many hand levers?

How many foot levers?

Purpose of each?

Can they be easily opcrated from seat?

\section{Frame.}

Form of steel used, angle, I beam, channel or square steel tube?

Do you consider frame strong and well balanced?...-

\section{Miscellaneous.}

Has binder a tongue truck?

Which of the grain binders studied do you prefer? 


\section{CORN BINDER.}

\section{General Information.}

Exercise No. 26.

Trade name and number?

Manufacturer?

Address?

Frame.

Form of steel used-angle, I beam, channcl or square steel tube?

Do you consider frame strong and well braced?......

Main Wheel.

Diameter? feet inches.

Width of tire? inches?

Bearings-plain, ball or roller,-self aligning?

\section{Side Wheel.}

Diameter? feet.

Width tire? -inches.

Bearings-plain, ball or roller?

Easily lubricated?

\section{Main Drive From Main Wheel.}

Gear or chain drive?

Width of links? inches.

Links steel or malleable?

Links with or without pins?

How is chain tightened?

\section{Counter Shaft.}

How many?

Bearings_-plain, ball or roller,-self aligning?

Can bearings be adjusted in wear?...........

\section{Crank Shaft.}

Bearings-plain, ball or roller,-self aligning?

Investigate operation of clutch?

\section{Sickle.}

How many sections?

How does size and thickness of section compare with that used on mower?

How is pitman connected to sickle?

Sections-plain or serrated?

Is sickle head protected?

Revolutions of crank shaft to 100 inches travel of machine?

Direction of rotation of fly wheer looking from driver's seat?

Any side knives?

Can they be adjusted? 


\section{Pitman.}

Material-wood or steel?

Easily removed if broken?

Bearings at crank easily lubricated?

Bushing bearing at crank end-iron, babbitt or bronze?

\section{Bevel Gear.}

How many on machine?

Can they be adjusted for wear?

Are they protected?

\section{Carrier Chains.}

How many?

Malleable or steel?

Lugs on every link?

How are chains tightened?

Travel of chains per 100 inches travel of machine? .

\section{Binder Attachment.}

Twine tension kind?

How many packers?

How many discharge arms?

Has needle a steel roller in eye?

How is height of band changed?

How many inches can band be changed?

Twine box handy to seat?

How many trips?

Does it hind bundles in vertical, inclined or horizontal position?

\section{Bundle Carriers.}

Kind of carrier?

Unloads by tipping or swinging?

If it hits an obstacle will it move out of the way?...

Will it scatter the bundles?

Does carrier raise from stubble before swinging into position?

\section{Levers.}

How many hand levers?

How many foot levers?

Purpose of each?

Can they be easily operated from seat?

\section{Miscellaneous.}

Has binder a tongue truck? 


\section{CORN BINDER.}

General Information.

Exercise No. 26.

Trade name and number?

Manufacturer?

Address?

\section{Frame.}

Form of steel used-angle, I beam, channcl or square steel tube?

Do you consider frame strong and well bracel? - -

\section{Main Wheel.}

Diameter? inches.

Width of tire? feet

Bearings-plain, ball or roller,-self aligning?

\section{Side Wheel.}

Diameter? feet.

Width tire? inches.

Bearings-plain, ball or roller?

Easily lubricated?

\section{Main Drive From Main Wheel.}

Gear or chain drive?

Width of links?

Links steel or malleable?

Links with or without pins?

How is chain tightened?

\section{Counter Shaft.}

How many?

Bearings - plain, ball or roller, - self aligning?

Can bearings be adjusted for wear?

\section{Cranic Shaft.}

Bearings-plain, ball or roller,-self aligning? Irvestigate operation of clutch?

Sickle.

How many sections?

How does size and thickness of section compare with that used on mowe:?

How is pitman connected to sickle?

Sections-plain or serwated?

Is sickle head proiected?

Revolutions of crank shaft to 100 inches travel of machine?

Direction of rotation of fly wheel looking from driver's seat?

Any side knives?

Can they be adjusted". 


\section{Pitman.}

Material-wood or steel?

Easily removed if broken?

Bearings at crank easily lubricated?

Bushing bearing at crank end-iron, babbitt or bronze?

\section{Bevel Gear.}

How many on machine?

Can they be adjusted for wear?

Are they protected?

\section{Carrier Chains.}

How many?

Malleable or steel?

Lugs on every link?

How are chains tightened?

Travel of chains per 100 inches travel of machine? inches.

\section{Binder Attachment.}

Twine tension kind?

How many packers?

How many discharge arms?

Has needle a steel roller in eye?

How is height of band changed?

How many inches can band be changed?

Twine box handy to seat?

How many trips?

Does it bind bundles in vertical, inclined or horizontal position?

\section{Bundle Carriers.}

Kind of carrier?

Unloads by tipping or swinging?

If it hits an obstacle will it move out of the way? Will it scatter the bundles?

Does carrier raise from stubble before swinging into position?

\section{Levers.}

How many hand levers?

How many foot levers?

Purpose of each?

Can they be easily operated from seat?

\section{Miscellaneous.}

Has binder a tongue truck?

Which of the corn binders studied do you prefer? 
POTATO DIGGER.

General Information.

Exercise No. 27.

Trade name and number?

Manufacturer?

Address?

\section{Elevator.}

Made of rods or dises?

Rods of uniform height or are some higher than others?

Provision for shaking apron?

Length of elevator?

Width of elevator?

Width of throat?

Number of rollers that support elevator?

Roller's easily oiled?

Rollers easily removed?

How is tension of apron adjusted?

Driven by gears or chain?

From one or both wheels?

\section{Shaker.}

Investigate its operation?

Is it adjustable?

\section{Levers.}

How many?

Purpose of each?

Wheels.

Diameter?

Width of tire?

Material-cast iron or steel?

Lugs?

Bearings protected against dirt?

Bearings easily lubricated?

Oil or grease?

Roller bearings?

\section{Miscellaneous.}

Tongue truck?

Easily thrown in and out of gear from seat?

Can digger be backed up?

Sacking attachment? 
General Information.

POTATO DIGGER.

Trade name and number?

Exercise No. 27.

Manufacturer?

Address?

\section{Elevator.}

Made of rods or dises?

Rods of uniform height or are some highey than others?

Provision for shaking apron?

Length of elevator?

Width of elevator?

Width of throat?

Number of rollers that support elevator?

Rollers easily oiled?

Rollers easily removed?

How is tension of apron adjusted?

Driven by gears or chain?

From one or both wheels?

\section{Shaker.}

Investigate its operation?

Is it adjustable?

\section{Levers.}

How many?

Purpose of each?

\section{Wheels.}

Diameter?

Width of tire?

Material-cast iron or steel?

Lugs?

Bearings protected against dirt?

Bearings easily lubricated?

Oil or grease?

Roller bearings?

\section{Miscellaneous.}

Tongue truck?

Easily thrown in and out of gear from seat?

Can digger be backed up?

Sacking attachment?

Which of diggers studied do you prefer? 
ENSILAGE CUTTER.

General Information.

Exercise No. 28.

Trade name and number?

Manufacturer?

Address?

Rated capacity? tons per hour.

Power required? H. P.

\section{Knives.}

Kind-radial, curved or spiral?

Length of cutting edge?................inches.

How many?

Thickness? inches.

How many bolts holding knife on?

Size of bolts?

Easily removed?

Easily sharpened?

Each linife adjustable to cutting edge?

\section{Cutter Head.}

Material-cast iron or steel?

R. P. M.?

Diameter? inches.

Diameter shaft? inches.

Cutter head accessible?

Adjustable to shear plate?

\section{Feeding Mechanism.}

Diameter feed rollers_..._.........inches.

Length feed rollers?.............inches.

Describe surface of feed rolls?

Spring or weight on upper roller?

Upper roller adapts itself to feed providing mori comes on one side than other?

All parts necessary to make changes of cut on machine all the time?

Maximum length of cut?..............inches.

Minimum length of cut?............inches.

Feed table apron-wood or steel?

Feed rollers driven by gearing or chain?

Is gearing or chain well protected?

\section{Levers.}

How many?

Purpose of each?

Reverse lever for emergencies, handy and quickly operated? 


\section{Elevator.}

Blower or carrier?

Diameter blower pipe?

How many fan blades?

Are blades renewable?

Fan attached to cutter head?

R. P. M. of blower?

Can speed of fan be varied?

How is silage fed to elevator?

How is fan housing cleaned when it becomes clogged"?

\section{Shear Plate.}

Naterial?

Adjustable?

Can it be reversed in order to get new cutting edge?

\section{Pulley.}

Diameter? .................. inches.

Width?

Rim speed is_........... feet per second.

Break pin?

Provision for taking up end play in main shaft?

\section{Frame.}

Wood, cast iron, steel (channel or angles)?

Bolted or riveted?

Mounted on trucks?

\section{Bearings.}

How many roller bearings?

How many self aligning boxes?

How many oil holes?

Do boxes have removable bearings?

\section{Miscellaneous.}

Knife grinding attachment?

How is length of cut changed on this machine?....

What lengths of cut can be made? 


\section{General Information.}

Exercise No. 28.

Trade name and number?

Manufacturer?

Address?

Rated capacity? tons per hour.

Power required? -H. P.

\section{Knives.}

Kind-radial, curved or spiral?

Length of cutting edge? ............. inches.

How many?

Thickness? inches.

How many bolts holding knife on?

Size of bolts?

Easily removed?

Easily sharpened?

Each knife adjustable to cutting edge?

\section{Cutter Head.}

Material-cast iron or steel?

R. P. M.?

Diameter? inches.

Diameter shaft? _..._._._._. inches.

Cutter head accessible?

Adjustable to shear plate?

\section{Feeding Mechanism.}

Diameter feed rollers_._._._._._._inches.

Length feed rollers?.............inches.

Describe surface of fecd rolls?

Spring or weight on upper roller?

Upper roller adapts itself to feed providing morc comes on one side than other?

All parts necessary to make changes of cut on machine all the time?

Maximum length of cut?._...........inches.

Minimum length of cut? inches.

Feed table apron-wood or steel?

Feed rollers driven by gearing or chain?

Is gearing or chain well protected?............

\section{Levers.}

How many?

Purpose of each?

Reverse lever for emergencies, handy and quickly operated? 


\section{Elevator.}

Blower or carrier?

Diameter blower pipe?

How many fan blades?

Are blades renewable?

I'an attached to cutter head?

R. P. M. of blower?

Can speed of fan be varied?

How is silage fed to elevator?

How is fan housing cleaned when it becomes clugged?

\section{Shear Plate.}

Material?

Adjustable?

Can it be reversed in order to get new cutting edge?

Pulley.

Diameter? inches.

Width? inches.

Rim speed is feet per second.

Break pin?

Provision for taking up end play in main shaft?

\section{Frame.}

Wood, cast iron, steel (channel or angles)?

Bolted or riveted?

Mounted on trucks?

Bearings.

How many roller bearings?

How many self aligning boxes?

How many oil holes?

Do boxes have removable bearings?

Miscellaneous.

Knife grinding attachment?

How is length of cut changed on this machine?

What lengths of cut ean be made? 
ENSILAGE CUTTER.

\section{General Information.}

Exercise No. 28.

Trade name and number?

Manufacturer?

Address?

Rated capacity? toms per hout:

Power required? H. $\mathrm{r}$.

\section{Knives.}

Kind-radial, curved or spiral?

Length of cutting erlge? ...............inches.

How many?

Thickness? inches.

How many bolts holding knife on?

Size of holts?

Easily removed?

Easily sharpened?

Fach knife arljustable to cutting colge?

\section{Cutter Head.}

Material-cast iron or steel?

R. P. MI.?

Diameter? inches.

Diameter shaft? inches.

Cutter head accessible?

Adjustable to shear nlate?

\section{Feeding Mechanism.}

Diameter feed rollers inches.

Length feed rollers? inches.

Describe surface of fond rolls?

Spring or weight on upper rolier?

Upuer roller arlapts itself to feed providiner ma: comes on one sirie than other?

All parts necess?ly to make changes of cut on minchine ali the tine?

Maximum length of cut? inches.

Minimum length of cut? inches.

Feed table apron-wood or steel.

Feed rollers driven by gearing or chain?

Is gearing oi chain well protected?

\section{Levers.}

How many?

Purpose of cach?

Reverse lever for emergencies, handy and quickly operated? 


\section{Elevatox.}

Blower or carrier?

Diameter blower pipe?

How many fan blades?

Are blades renewable?

Fan attached to cutter head?

R. P. M. of blower?

Can speed of fan be varied?

How is silage fed to elevator?

How is fan housing cleaned when it becomes clogged?

\section{Shear Plate.}

Material?

Adjustable?

Can it be reversed in order to get new cutting edge?

Pulley.

Diameter?

Width?

Rim speed is_._._._.

Break pin?

Provision for taking up end play in main shaft?...--

Frame.

Wood, cast iron, steel (channel or angles)?

Bolted or riveted?

Mounted on trucks?

\section{Bearings.}

How many roller bearings?

How many self aligning boxes?

How many oil holes?

Do boxes have removable bearings?

\section{Miscellaneous.}

Knife grinding attachment?

How is length of cut changed on this machine?....

What lengths of cut can be made?

Which cutter studied do you prefer? 
Trade name and number?

Manufacturer?

Address?

Vertical or horizontal?

Materials can be ground-shelled corn; corn and cob; corn, cob and shuck; corn cobs; velvet beans in pod, Kafir corn; milo maize, feterita?

Capacity shelled corn, pounds per hour?

Power-sweep or pulley?

Power required?................ P.

\section{Grinding Device.}

Buhrs-flat, cylindrical or conical?

Buhrs-simple or duplex?

Buhrs material-chilled iron, steel or stone?

R. P. M. of buhrs?

Safety device for stone, nails, bolts, etc.?

Safety device consist-spring or break pin?

How is adjustment of fineness of feed made?

\section{Hopper.}

Divided?

Capacity?_._._.

Material-wood, steel or iron?

Feed.

Force or gravity?

Crusher-cast iron or steel?

\section{Frame.}

Material-wood, iron or steel?

Well made and braced?

\section{Levers.}

How many?

Purpose of each?

\section{Miscellaneous.}

Elevator attachment?

Fly wheel?

Drive pulley inside or outside frame?

Width pulley?............. inches.

Rim speed of pulley is _._._._. feet per second. 


\section{BUHR FEED MILL.}

\section{General Information.}

Exercise No. 29.

Trade name and number?

Manufacturer?

Address?

Vertical or" horizontal?

Materials can be ground-shelled com; corn and cob; corn, cob and shuck; corn cobs; velvet beans in pod, Kafir corn; milo maize, feterita?

Capacity shelled corn, pounds per hour?

Power-sweep or pulley?

Power required? H. P.

\section{Grinding Device.}

Buhrs-flat, cylindrical or conical?

Buhrs material-chilled iron, steel or stone?

R. P. M. of buhrs?

Safety device for stone, nails, bolts, etc.?

Safety device consist-spring or break pin?

How is adjustment of fineness of feed made?.....

\section{Hopper.}

Divided?

Capacity? -bushels.

Material-wood, steel or iron?

Feed.

Force or gravity?

Crusher-cast iron or steel?

\section{Frame.}

Material-wood, iron or steel?

Well made and braced?

\section{Levers.}

How many?

Purpose of each?

\section{Miscellaneous.}

Elevator attachment?

Fly wheel?

Drive pulley inside or outside frame?

Width pulley?

Rim speed of pulley is _.._._._. fect per second.

Which mill studied do you prefer? 
HAMMER FEED MILL.

General Information.

Exercise No. 30.

Trade name and number?

Manufacturer?

Address?

Materials can be ground-shelled corn; corn and cob; corn; cob and shuck; corn cobs; velvet beans in pod; hay; straw; Kafir corn; milo maize; feterita?

Capacity shelled corn, pounds per hour?

Power required to operate? H.P.

\section{Hammers.}

Rigid or loose on shaft?

Size_width? _._._...inches; thickness_.......inche:. Length? _._.

Number of hammers in row?

Number of rows of hammers?

One or: two eylinders?

Can hammers be reversed when worn?

R.P.M. of hammers?

How is adjustment for fineness of feed made?

\section{Hopper.}

Divided?

Capacity? bushels.

Material-cast iron, cast steel, or sheet steel?

\section{Screens.}

Wire or sheet steel with holes cut in?

Easily put in and taken out?

\section{Frame.}

Material-wood, iron, or steel?

Well made and braced?

\section{Levers.}

How many?

Purpose of each?

\section{Miscellaneous.}

Plain, roller or ball bearings on shaft?

Elevator attachment?

Fly wheel?

Width of pulley? inches.

Rim speed of pulley is feet per second. 


\section{HAMMER FEED MILL.}

\section{General Information.}

Exercise No. 30.

Trade name and number?

Manufacturer?

Address?

Materials can be ground-shelled corn; corn and cob; corn; cob and shuck; corn cobs; velvet beans in pod; hay; straw; Kafir corn; milo maize; feterita?

Capacity shelled corn, pounds per hour?

Power required to operate? H.P.

\section{Hammers.}

Rigid or loose on shaft?

Size — width? _._._._. inches; thickness_._._._._inches.

Length? inches.

Number of hammers in row?

Number of rows of hammers?

One or two cylinders?

Can hammers be reversed when worn?

R.P.M. of hammers?

How is adjustment for fineness of feed made?

\section{Hopper.}

Divided?

Capacity? bushels.

Material-cast iron, cast sceel, or sheet steel?

\section{Screens.}

Wire or sheet steel with holes cut in?

Easily put in and taken out?

\section{Frame.}

Material-wood, iron, or steel?

Well made and braced?

\section{Levers.}

Huw many?

Purpose of each?

\section{Miscellaneous.}

Plain, roller or ball bearings on shaft?

Elevator attachment?

Fly wheel?

Width of pulley? inches.

Rim speed of pulley is feet per second.

Which mill studied do you prefer? 
FANNING MILLS.

General Information.

Exercise No. 31.

Trade name and number?

Manufacturer?

Address?

Operated by hand or power?

Capacity cleaning oats? bu. per hour.

\section{Hopper.}

Size? bushels.

Agitator?

How feed regulated?

Will feed stop when machine stops?

\section{Shoe.}

Side or end shake?

Can shaking be adjusted from a long stroke to a short quick one?

Number of screens and sieres that shoes will handle?

Is shoe substantial?

\section{Screens.}

Size-width? feet.

How many?

Kinds of openings-slots or round?

Can pitch of sereens be adjusted?

\section{Fan.}

Where located?

R. P. M.?

How is blast regulated?

\section{Miscellaneous.}

Machine well built and substantial? ...........

Wood throughout?

On what principle does machine operate?-size, shape or weight of kernel?

What seeds will this machine clean: wheat, rye, oats, barley, peas, beans, clover, alfalfa, lespedeza, timothy, alsike, red top, flax or millet?

Corn grading attachment?

Elevator and bagger? 


\section{FANNING MILLS.}

\section{General Information.}

Exercise No. 31.

Trade name and number:

Mianufacturer?

Adidress?

Operated by hand or power?

Capacity cleaning vat:? _._._...... bu. per hout:

\section{Hopper.}

Size? ............. bushek.

Agitator?

How feed regulated?

Will feerl stop when machine stops?

\section{Shoe.}

Side or end shake?

Can shaking be adjusted from a long stroke to a short quici one?

Number of screens and sieves that shoes will handle?

Is shoe substantial?

\section{Screens.}

Size_width?__..._.__feet; Length__..._._. feet.

How many?

Kinds of openings-slots or round?

Can pitch of sereans be aljusted?

Fan.

Grhere located?

R. I. M.?

How is blast renulated".

\section{Miscellaneous.}

Machine well built and substantial?

Wood throughout?

On what principle does machine operate?-size, shape or weight of kernel?

What seeds will this machine clean: wheat, rye, oats, barley, peas, beans, clover, alfalfa, lespedeza, timothy, alsike, red top, flax or millet?

Corn srading attadiment?

Elevator and bagwer?

Which of the fanning mills studied do you prefer? - 
MANURE SPREADERS.

General Information.

Exercise No. 32.

Trade name and number?

Manufacturer?

Address?

Rated capacity? bushels.

Eox.

Material-wood or steel?

Dimensions? Width_._._Length_._._._. Depth_..._.

Contents box? cu. ft._._._._._._bushels

(1 bushel equals 1.25 cubic feet).

Height of top of box above ground?..._._._feet.

Is box wider at rear than at front?

Does bed slope to rear?

How much?

Does box have tight bottom?

Does apron have two or three rails to roll on?

Can sides be let down?

\section{Wheels.}

Material-wood or steel?

Size-diameter of front__._._- ; rear___.__f feet.

Width of front__.____; rear_______feet.

Kind traction lugs?

Wheels track?

Width of track? Front__._.____inches.

Width of track? Rear._._._._._. inches.

Diameter of axles?

Spokes cast in hub and upset in rim?

Rims flanged?

\section{Beater (Main)}

In one section or how many? ........

Diameter to tips of teeth?

Length of teeth?

Teeth sharp or blunt?

Are teeth in regular or irregular rows?

How are teeth fastened in?

Distance beater projects below top or apron?.... in.

How many bars?

Bars-wood or steel?

Have bars center support?

Can beater be operated without moring apron? 
Beater (Auxiliary).

Diameter to tips of teeth?

How many bars?

Bars-wood or steel?

Length of teeth in inches?

Which direction does this turn with relation to

Rake. main beater?

Has spreader a rake?

Movable or stationary?

How many teeth?

Length of teeth? inches.

Is it flexible enough to allow passage of larger Apron. lumps?

Endless or return?

Does apron slide over solid floor?

Has apron rollers?

How many rollers?

Apron self cleaning?

Can apron be tightened?

Return apron by power, hand or both?

How are slats fastened to apron?

How is apron tightened?

\section{Beater Drive.}

Power transmitted from drive wheel by gears, chain or both?

Chain-steel or malleable, with or without steel pins

Chain tightener?

Driven from one or both sides?

When starting up does beater retreat a little at first?

Size of beater shaft? -inches.

Gearing well protected?

Where is clutch located?

Number of revolutions main beater makes to one revolution of wheels?

Number of revolutions auxiliary beater makes to one revolution of wheels?

How does number of feet travelled by outside of main beater and wheel compare?............ Beater travel?.......feet? wheel travel? _.......feet. 
Apron Drive.

Rachet or worm?

How is power obtained to drive apron?

How many speeds?

Can speeds be changed while spreader is in motion?

Does worm run in oil?

Is rachet single or double?

If rachet drive is there any provision made to mevent apron from racing when groing up hill?.... Gearing well protected?

Distance travelled by apron during one revolution of main wheel?_-max..._._._feet; min.._._._.ft.

\section{Bearings.}

Main axle have roller bearings?

Beaters have roller bearings?

How many roller bearings on machine?

Do all roller bearings have self aligning boxes?

How lubricated-by oil or grease cups?

How many oil holes?......._. grease cupson spreader.

\section{Levers.}

How many hand?

How many foot?

Purpose of each?

Can apron be run against beater without running beater?

Can both forward and backward motion of apron be thrown in at the same time?

Levers casily operated from seat?

\section{Hitch.}

Two or three horse combination?

Thrills used with three horses?

Tongue attached to front axle or frame?

Auto type of steering?

Diameter smallest circle spreader will turn in?_-_ft.

\section{Miscellaneous.}

What is the highest obstruction spreader will clear?

Is there a rear end gate?

If not, what provision is made to assist in starting to unload?

How operated?

Is there a wide spread attachment?

What kind? 


\section{MANURE SPREADERS.}

General Information.

Exercise No. 32 .

Trede name and number?

Manufacturer?

Address?

Rated capacity? bushels.

Box.

Material-wood or steel?

Dimensions? Width__.__Length______Depth__._._-

Contents box?_._._._. cu. ft._._._._._bushels

(1 bushel equals 1.25 cubic feet).

Height of top of box above ground?_._._._. feet.

Is box wider at rear than at front?

Does bed slope to rear?

How much?

Does box have tight bottom?

Does apron have two or three rails to roll on?

Can sides be let down?

\section{Wheels.}

Material-wood or steel?

Size-diameter of front_..._._; rear__._._feet.

Width of front_....._; rear_.......feet.

Kind traction lugs?

Wheels track?

Width of track? Front. inches.

Width of track? Rear._._._._. inches.

Diameter of axles?

Spokes cast in hub and upset in rim?

Rims flanged?

\section{Beater (Main)}

In one section or how many?

Diameter to tips of teeth? feet.

Length of teeth? inches.

Teeth sharp or blunt?

Are teeth in regular or irregular rows? .......... How are teeth fastened in?

Distance beater projects below ton or apron?

How many bars?

Bars-wood or steel?

Have bars center support?

Can beater be operated without moving apron?..... 
Beater (Auxiliary).

Diameter to tips of teeth?

How many bars?

Bars-wood or steel?

Length of teeth in inches?

Which direction does this turn with relation to Rake. main beater?

Has spreader a rake?

Movable or stationary?

How many teeth?

Length of teeth?

Is it flexible enough to allow passage of larger lumps?

Apron.

Endless or return?

Does apron slide over solid floor? .................

Has apron rollers?

How many rollers?

Apron self cleaning?

Can apron be tightened?

Return apron by power, hand or both?

How are slats fastened to apron?

How is apron tightened?

\section{Beater Drive.}

Power transmitted from drive wheel by gears, chain or both?

Chain-steel or malleable, with or without steel pins

Chain tightener?

Driven from one or both sides?

When starting up does beater retreat a little at first?

Size of beater shaft? inches.

Gearing well protected?

Where is clutch located?

Number of revolutions main beater makes to one revolution of wheels?

Number of revolutions auxiliary beater makes to one revolution of wheels?

How does number of feet travelled by outside of main beater and wheel compare?

Beater travel?.......feet? wheel travel? feet. 
Apron Drive.

Rachet or worm?

How is power obtained to drive apron? ..........

How many speeds?

Can speeds be changed while spreader is in motion?

Does worm run in oil?

Is rachet single or double?

If rachet drive is there any provision made to prevent apron from racing when groing up hill?...-

Gearing well protected?

Distance travelled by apron during one revolution of main wheel?_-max........ feet; min....._._ft.

\section{Bearings.}

Main axle have roller bearings?

Beater's have roller bearings?

How many roller bearings on machine:

Do all roller bearings have self aligning boxes?

How lubricatech-by oil or grease cups?

How many oil holes?......... grease cups-........ on spreader.

\section{Levers.}

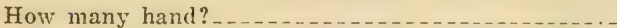

How many foot?

Purpose of each?

Can apron be run against beater without running beater?

Can both forward and backward motion of apron be thrown in at the same time?

Levers easily operated from seat?.............

\section{Hitch.}

Two or three horse combination?...............

Thrills used with three horses?

Tongue attached to front axle or frame?

Auto type of steering?

Diameter smallest circle spreader will turn in?_._-_ft.

\section{Miscellaneous.}

What is the highest obstruction spreader will clear?

Is there a rear end gate?

How operated?

If not, what provision is made to assist in starting to unload?

Is there a wicie spread attachment?

What kind? 
MANURE SPKEADERS.

General Information.

Exercise No. 32.

'Trade name and number?.

Manufacturer?

Address?

Rated capacity? bushels.

Box.

Material-wood or steel?

Dimensions? Width__.__Length_._._._Depth_......

Contents box?

cu. ft.......... bushels ( 1 bushel equals 1.25 cubic feet).

Height of top of box above ground?_._._._feet.

Is box wider at rear than at front?...............

Does bed slope to rear?

How much?

Does boxes have tight bottom?

Does apron have two or three rails to roll on?

Can sides be let down?

\section{Wheels.}

Material-wood or steel?

Size_diameter of front_......; rear_.____feet.

Width of front_._._._. ; rear__._..._feet.

Kind traction lugs?

Wheels track?

Width of track? Front__._._._._. inches.

Width of track? Rear._........_.inches.

Diameter of axles?................ inches.

Spokes cast in hub and upset in rim? Rims flanged?

Beater (Main).

In one section or how many?

Diameter to tips of teeth? feet.

Length of teeth? -inches.

Teeth sharp or blunt?

Are teeth in regular or irregular rows?

How are teeth fastened in?

Distance beater projects below top or apron?_-_-in.

How many bars?

Bars-wood or steel?

Have bars center support?

Can beater be operated without moving apron? 
Beater (Auxiliary).

Diameter to tips of teeth?

How many bars?

Bars-wood or steel?

Length of teeth in inches?

Which direction does this turn with relation to main beater?

\section{Rake.}

Has spreader a rake?

Movable or stationary?

How many teeth?

Length of teeth? -inehes.

Is it flexible enough to allow passage of larger lumps?

\section{Apron.}

Endless or return?

Does apron slide over solid floor?

Has apron rollers?

How many rollers?

Apron self cleaning?

Can apron be tightened?

Return apron by power, hand or both?

How are slats fastened to apron?

How is apron tightened?

\section{Beater Drive.}

Power transmitted from drive wheel by gears, chain or both?

Chain-steel or malleable, with or without steel pins

Chain tightener?

Driven from one or both sides?

When starting up does beater retreat a little at first?

Size of beater shaft? inches.

Gearing well protected?

Where is clutch located?

Number of revolutions main beater makes to one revolution of wheels?

Number of revolutions auxiliary beater makes to one revolution of wheels?

How does number of feet travelled by outside of main beater and wheel compare?...........

Beater travel?....._feet? wheel travel?_..... feet. 


\section{Apron Drive.}

Rachet or worm?

How is power obtained to drive apron?...........

How many speeds?

Can speeds be changed while sprearler is in motion?

Does worm run in oil?

Is rachet single or double?

If rachet drive is there any provision made to prevent apron from racing when going up hill?....

Gearing well protected?

Distance travelled by apron during one revolution of main wheel?_-max._._..._feet; min.........ft.

\section{Bearings.}

Main axle have roller bearings?

Beaters have roller bearings?

How many roller bearings on machine?

Do all roller bearings have self aligning boxes?

How lubricated-by oil or grease cups?

How many oil holes? grease cups?

on spreader.

\section{Levers.}

How many hand?

How many foot?

Purpose of each?

Can apron be run against beater without running beater?

Can both forward and backward motion of apron be thrown in at the same time?

Levers easily operated from seat?

\section{Hitch.}

Two or three horse combination?

Thrills used with three horses?

Tongue attached to front axle or frame?

Auto type of steering?

Diameter smallest circle spreader will turn in?_-.-ft.

\section{Miscellaneous.}

What is the highest ohstruction spreatel will clear?

Is there a rear end gate?

How operated?

If not, what provision is made to assist in starting to unload?

Is there a wide spread attachment?

What kind?

Which of the sprearlers studied do you prefer?.... 


\section{LIME SPREADERS.}

\section{General Information.}

Exercise No. 33.

Trade name and number?

Manufacturer?

Address?

Box.

Cubical contents? cu. inches.

Approximate pounds lime it will hold? lbs.

Shape of end?

Well trussed?

Material in box?

What kind of agitator?

How is agitator driven?

Cover in one or two pieces?

\section{Force Feed.}

Type?

Material?

\section{Valves.}

How is amount of lime distribution regulated?

What are the limits in pounds per acre?

How is power transmitted to valve shaft?

\section{Levers.}

How many?

Purpose of each?

\section{Wheels.}

Wood or steel?

Diameter? _..._.

Width of tire?

Width of track?

Type of bearings on axles-plain, roller,-self aligning.

\section{Miscellaneous.}

Seat or foot board?

Land measure provided?

Can it be adjusted? 
LIME SPREADERS.

General Information.

Exercise No. 33.

Trade name and number?

Manufacturer?

Address?

Box.

Cubical contents? cu. inches.

Approximate pounds lime it will hold?_._._._. lbs.

Shape of end?

Well trussed?

Material in box?

What kind of agitator?

How is agitator driven?

Cover in one or two pieces?

\section{Force Feed.}

Type?

Material?

\section{Valres.}

How is amount of lime distribution regulated?

What are the limits in pounds per acre?

How is power transmitted to valve shaft?

\section{Levers.}

How many?

Purpose of each?

Wheels.

Wood or steel?

Diameter? _... feet.

Width of tire?

Width of track?

Type of bearings on axles-plain, roller,-self aligning.

\section{Miscellaneous.}

Seat or foot board?

Land measure provided?

Can it be aljusted?

Which of the spreaders studied do : (11 prefor?...- 


\section{WAGONS:}

General Information.

Trade name and number?

Manufacturer?

Address?

Size?

Capacity?

lbs.

\section{Wheels.}

Material-wood or steel?

Bore of hubs-straight or tapered?

Diameter of front wheels?__._. feet_.____inches.

Diameter of rear wheels?_._._. feet__._._inches.

Width of tires?

Thickness of tires? inches.

Width of track?........ feet_._._._. inches.

Amount of dish?

Amount of front gather?._._._. inches.

Amount of bottom gather?........inches.

Felloe bent or sawed?

Axles.

Material-wood or steel?

Reinforced or trussed?

Skein-cast or steel?

Skein diameter?

Skein length? ...........................

\section{Bolsters.}

Material-wood ox steel?

Provided with rings?

Well made and reinforced?

Reach.

Material-wood or steel?

Adjustable as to length?

Metal sleeve through rear bolster?

Fifth Wheel.

Has wagon a fifth wheel?

Well made?

Box.

Size-length_........._feet; width. feet;

depth feet.

Rubbing plates for bolsters?

Iron plate to prevent front wheel from rubbing box?

Can upper box be locked to lower one?

How many cross pieces under floor of box? Thickness of floor?

Endgate-straight or broken?

Seat-well made?

Hitch.

Substantial pole?

Double trees well made and reinforced?

Drop or army tongue?

Stay chains?

Miscellaneous.

Brake? 
WAGONS.

General Information.

Exercise No. 34

Trade name and number?

Manufacturer?

Address?

Size?

Capacity? lbs.

Wheels.

Material-wood or steel?

Bore of hubs-straight or tapered?

Diameter of front wheels?....... feet.......inches.

Diameter of rear wheels?._._._feet_._._.inches.

Width of tires?

Thickness of tires?

Width of track? _._..... feet_........inches.

Amount of dish?

Amount of front gather?

Amount of bottom gather?........inches.

Felloe bent or sawed ?

Axles.

Material-wood or steel?

Reinforced or trussed?

Skein-cast or steel?

Skein diameter?

Skein length? .................. inches.

\section{Bolsters.}

Material-wood or steel?

Provided with rings?

Well made and reinforced?

Reach.

Material-wood or steel?

Adjustable as to length?

Metal sleeve through rear bolster?

Fifth Wheel.

Has wagon a fifth wheel?

Well made?

Box.

Size-length _._._....feet; width_.......... feet; depth............ feet.

Rubbing plates for bolsters?

Iron plate to prevent front wheel from rubbing box?

Can upper box be locked to lower one? ......... How many cross pieces under floor of box? Thickness of floor? _................ inches.

Endgate-straight or broken?

Seat-well made?

Hitch.

Substantial pole?

Double trees well made and reinforced?

Drop or army tongue?

Stay chains?

Miscelláneous.

Brake?

Which of wagons studied do you prefer? 
BARREL SPRAYER.

General Information.

Exercise No. 35.

Trade name and number?

Manufacturer?

Address?

Barrel.

Capacity? -gals.

Vertical or horizontal?

On trucks?

Well made?

Will mixture slop out?

Kind of agitator-dasher or propeller?

Investigate its action?

\section{Pump.}

Horizontal or vertical?

What kind of valves?

Valve seats-iron, brass, or glass?

Valve in piston?

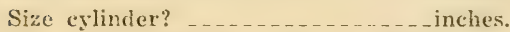

Length of stroke?

Where is air chamber?

Pump securely fastened?

Pump easy to operate?

\section{Nozzle.}

How many?

Type of nozzle?

Length and size of hose?..._feet of _.._inch hose.

Can nozzle be easily cleaned and adjusted? 
BARREL SPRAYER.

\section{General Information.}

Exiercise No. 35.

Trade name and number?

Manufacturer?

Address?

\section{Barrel.}

Capacity? _............. gals.

Vertical or horizontal?

On trucks?

Well made?

Will mixture slop out?

Kind of agitator-dasher or propeller?

Investigate its action?

\section{Pump.}

Horizontal or vertical?

What kind of valves?

Valve seats-iron, brass, or glass?

Valve in piston?

Size cylinder? inches.

Length of stroke?

Where is air chamber?

Pump securely fastened?

Pump easy to operate?

\section{Nozzle.}

How many?

Type of nozzle?

Length and size of hose?... feet of _.._inch hose.

Can nozzle be easily cleaned and adjusted?

\section{Miscellaneous.}

Which sprayer studied do you prefer? 


\section{POWER SPRAYER.}

General Information.

Exercise No. 36.

Trade name and number?

Manufacturer?

Address?

Tank (Solution).

Capacity? -gallons.

Shape?

Material?-steel or wood?

How is tank filled?

How is tank drained?

Kind of agitator?

How is agitator driven?

How is suction strainer removed?

\section{Pump.}

Type of pump?

If plunger, how many cylinder?

Can cylinders be drained?

What kind of valves?

Valve seats,-iron, brass, or glass?

Size of cylinder? ............... inches.

Length of stroke?

Single or double acting?

Pump securely fastened?

How are cylinders drained?

How is pressure regulated?

Can air be supplied to air dome?

\section{Power.}

H. P. of engine?

Trade name and number?

Manufacturer?

Address?

R. P. M.?

How many cylinders?

Horizontal or vertical?

Power transmitted to pump by direct gears, connecting rod or belt?

Engine fastened securely to base? 


\section{Nozzles.}

How many?

Type of nozzle?

How many lines of hose?

Length of hose?........ feet of .... . inch hose.

Can nozzle be easily cleaned and adjusted?.......

Material in extension rods?

Length of rods?

\section{Truck.}

Diameter whecls? feet.

Width of tire? inches.

Width of tread? inches.

Material in wheels-wood or steel?

Does truck appear well built and strong enough to handle the heavy load and vibration?

What size cirele can turi in?......... fert.

\section{Tower.}

Material-steel or wood?

Where located on frame?

Height of top above ground?

Anything to pievent operator from falling off tower?

\section{Miscellaneous.}

Is machine easily lubricated?

Where is relief ralve locater?

What is its purpose? 


\section{POWER SPRAYER.}

General Information.

Exercise No. 36.

Trade name and number?

Manufacturer?

Address?

Tank (Solution).

Capacity? -gallons.

Shape?

Material? - steel or wood?

How is tank filled?

How is tank drained?

Kind of agitator?

How is agitator driven?

How is suction strainer removed?

Pump.

Type of pump?

If plunger, how many cylinder?

Can cylinders be drained?

What kind of valves?

Valve seats,-iron, brass, or glass?

Size of cylinder?

Length of stroke?

Single or double acting?

Pump securely fastened?

How are cylinders drained?

How is pressure regulated?

Can air be supplied to air dome?

\section{Power.}

H. P. of engine?

Trade name and number?

Manufacturer?

Address?

R. P. M.?

How many cylinders?

Horizontal or vertical?

Power transmitted to pump by direct gears, connecting rod or belt?

Engine fastened securely to base? 


\section{Nozzles.}

How many?

Type of nozzle?

How many lines of hose?

Length of hose? feet of ........ inch hose.

Can nozzle be easily cleaned and adjusted?

Material in extension rods?

Length of rods? fieet.

\section{Truck.}

Diameter wheels? feet.

Width of tire? inches.

Width of tread? inches.

Material in wheels-wood or steel?

Does truck appear well built and strong enough to handle the heavy load and vibration?

What size circle can turn in? leet.

Tower.

Material-steel or wood?

Where located on frame?

Height of top above ground? feet.

Anything to prevent operator from falling off tower"

\section{Miscellaneous.}

Is machine easily lubricated?

What is its purpose?

Which of the sprayers studied do you prefer? 


\section{EVENERS.}

Instructions.

Exercise No. 37.

Make sketches below and on the next page of the eveners assigned by the instructor. Show the following dimensions: Length of single trees, double trees, eveners; distance between all holes and the position of the holes (that is whether they are in line or not). Be careful to make sketches clear and neat. Under each sketch note the following; - how many horses the evener is for, machine that evener is intended to be used on, and material of which it is made.

Also show by dotted lines the relative positions of each evener and the relative length of lever arms when evener is swung 30 degrees from normal. Also note above each figure the load of each horse when the evener is in this position and the total pull is $300 \mathrm{lbs}$. 


\section{EVENERS.}

(Continued). 


\section{SULKY AND GANG MOULDBOARD PLOW} ASSEMBLING.

Instructions.

Exercise No. 38d

Take apart and reassemble one sulky or gang mouldboard plow.

\section{Taking Apart.}

Take apart in the following order:

Remove seat.

Remove levers.

Remove coulters.

Remove weed hook.

Remove plow bottom and beams.

Remove wheels.

Call attention of the instructor to the fact that you now have plow disassembled.

\section{Reassemble.}

Put plow back together in the reverse order that you took it apart.

\section{Report.}

Trade name and number?

Manufacturer?

Address?

Time required to do work?

Date_....................., $192 \ldots$ 
MOWER ASSEMBLING.

\section{Instructions.}

Exercise No. 39.

Take one mower apart and reassemble and fill out report.

\section{Taking Apart.}

Remove each part in the following order, paying attention to how and where each piece goes.

Remove seat.

Sickle.

Pitman.

Inside divider and shoe.

Grass board and outside shoe.

Draw bar.

Levers.

Cutter bar.

Tongue.

Wheels.

Call attention of instructor that you have the mower disassembled.

\section{Reassemble.}

Put back together in reverse order that it was taken. apart. See that it works all right.

\section{Report.}

Trade name and number? .....................

Manufacturer?

Address?

Date $192 \ldots$

Time required to do work? hours.

Number of men working?

Note:-Any broken parts found or any missing parts noted report facts to instructor. 


\section{MOWER REPAIR.}

In'structions.

Exercise No. 40.

A mower just as it quits work at the end of the season will be assigned to the class. This mower is to be entirely overhauled, cleaned, adjusted and new parts put in whereever necessary. Go over the machine in the following order:

Wheels.

Take off wheels, remove pawls, examine, clean, and put back. Take up all play on axle by means of washers.

\section{Gearing.}

Clean gearing, determine if gears mesh properly; if not, adjust, or if too badly worn, put in new one. Investigate bearings.

\section{Crank Shaft.}

Investigate bearings.

\section{Pitman.}

Investigate bearings. If pitman badly damaged, put in new one. Straighten bar in front of pitman if it is bent.

\section{Cutter Bar.}

Line up. Investigate ledger plates, line up guards. Examine grass board and inside and outside shoes.

\section{Levers.}

Hitch.

Investigate operation.

Examine carefully-draft rods, double trees and neck yoke.

After machine is thoroughly overhauled and put in first-class shape, be sure all grease and dirt are off, thon paint it.

\section{Report.}

Trade name and number?

Manufacturer?

Address?

Width of cut?

Number of years has been operated?

Time required to put in shape?

Number of men working?

Amount of paint used? quart:

List of repairs used:

\begin{tabular}{l|c|c|c}
\hline Catalog No. & Name of Pieces & Price \\
\hline & & \\
& & \\
\hline
\end{tabular}




\section{BINDER ATTACHMENT ADJUSTMENT.}

\section{Instructions.}

Exercise No. 41 .

Adjust binder attachment on grain binder so it will tie small tight bundles. Tie ten bundles in order to be sure that it will not miss. Readjust so it will tie large tight bundles. Tie ten bundle's with it adjusted this way. When finished fill in report at bottom of page.

The following instructions will be of assistance in making the adjustments and if anything should go wrongr they will assist in finding just what the trouble is.

In adjustment of the spring's for tension it would be well to turn the nut only $1 / 1$ turn at a time until the proper tension is obained.

Cord holder or twine disc spring. This should grip the twine tight enough that thore is only a slight slippage of the twine in the dise when linotter revolves. If too tight, twine is broken. If too loose, twine will slip out from the dise.

Knotter spring. If too tight, twine wll be broken when knot is tied. If too loose, the knot will not be tied tight and may come undone when the bundle is handled.

Bundle sizer spring. 'This is the spring whose tension must be overcome to throw binder into gear for tieing a bundle. It regulates the tightness of packing, and to some extent the size of bundle. If band is loose on bundle this spring is probably too loose. Do not attempt to remedy a loose band by making twine tension very tight.

Twine tension. This should be only tight enough to keep the slack out of the twine. It is not used to make the machine tie tight bundles.

Knife. The knife should be snug up against the twine at the instant the knotter closes so the next movement will cut the twine and strip the twine from the linotter. If it is attached by a malleable arm, the arm may be bent. Knife must be sharp.

Needle. The needle is of malleable iron, and somelimes gets sprung up so that it does not deposit the twine in the twine disc. It should clear the twine dise by $1 / 4$ inch and pass over far enough to make sure of nlacing twine in the dise. It may be bent to the proper shape if it has been sprung.

\section{Report.}

Trade name and number?

Manufacturer?

Address?

Chain or gear drive?

Has the knotter a stripper?

How do you change the size of bundles?

How do you change the tightness of bands?...... 
BINDER ATTACHMENT ASSEMBLING.

Instructions.

Eercise No. 42.

Take apart one binder attachment in order given below and fill in report at bottom of page.

\section{Taking Apart.}

Remove each part in the following order, paying attention to how and where each piece goes:

Remove pitman and rock lever.

Remove main gear.

Remove needle.

Remove packers.

Remove clutch ratchet.

Remove clutch dog.

Remove springs.

Remove knotter hook.

Remove stripper and knife.

Remove twine holder.

Call attention of the instructor to the fact that you now have attachment disassembled.

\section{Reassemble.}

Put back together again in the reverse order that you took it apart. See that it works right.

\section{Report.}

Trade name and number?

Manufacturer?

Address?

Chain, lever or gear drive?

Has knotter a stripper?

Can adjustment be made for wear in twine holdex?

Steel rollers in eye of needles?

Date 192

Time required to do work?

Number of men doing work? 


\section{CORN PLANTER CALIBRATION.}

\section{Instrucrions.}

Exercise No. 43.

Calibrate a two-row corn planter dropping one, two and three kernels to the hill for 100 hills, using unsorted corn and sorted corn. Keep a record of the number of kernels dropped for each hill and record in table. Use plate that will give best results.

\section{Report.}

Trade name and number?......

Manufacturer?

Address?

Variety of corn used?

\section{Unsorted Corn.}

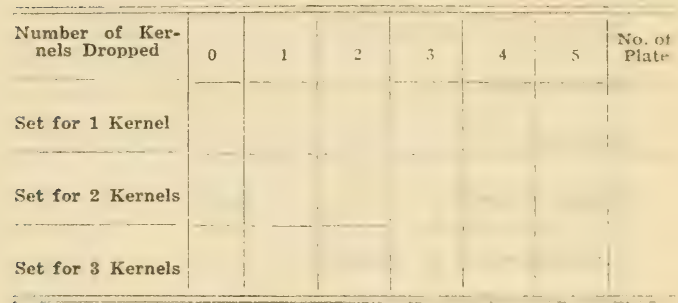

Sorted Corn.

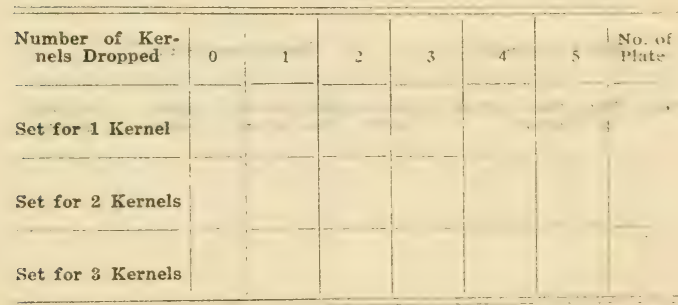




\section{GRAIN DRILL CALIBRATION.}

Instructions.

Exercise No. 44.

Calibrate a grain drill with two different linds of seed, make two tests with each seed, sowing different amounts each time.

Measure width of drill and circumference of wheel in feet. Determine the number of revolutions that wheel must turn in order to plant an acre.

Get from instructor sufficient clean seed to over half fill seed box. He will also tell you the amounts to sow per acre. Set the drill to sow one of these amounts. Put under each spout a separate vessel, such as a paper sack, to catch the seed. Turn wheel until seed is running in good shape from each spout. Then empty each sack back in seed box. Then start calibration-turn wheel number of revolutions to plant one-half acre. Be careful to turn wheel at about same speed as it will run in field.

\section{Report.}

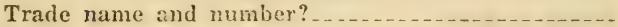

Manufacturer?

Address?

Width of drill? feet.

Circumference of wheels?

Revolution of wheels to sow acre?

Fill out the following tables:

Kind of seed? ........ Rates per Acre?

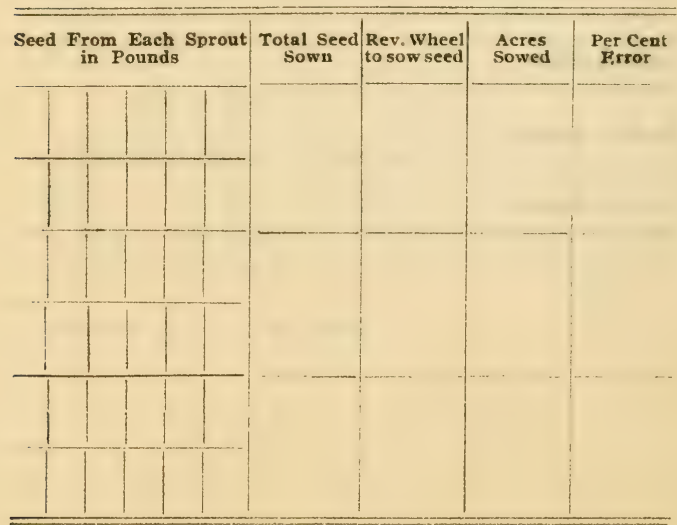




\section{GRAIN DRILL CALIBRATION.}

(Continued)

Kind of seed?

Rates per Acre?

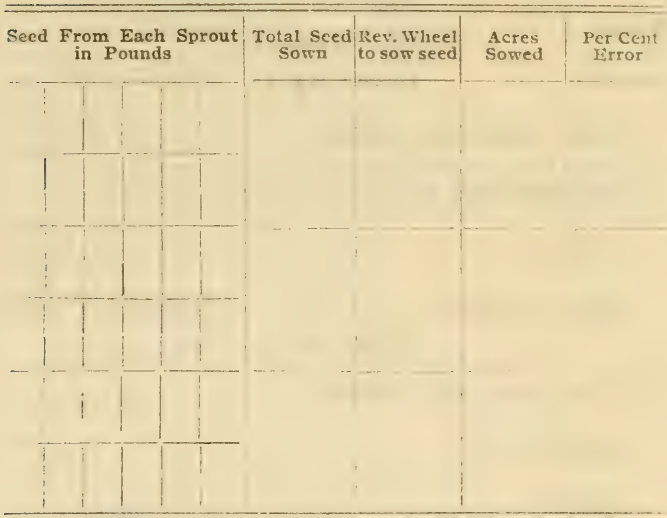




\section{CORN GRADER TEST.}

Instructions.

Exercise No. 45.

Using two different corn graders, grade five ears of corn with each. Make report as follows:

Report.

\section{General Information \\ Grader No. 1.}

Trade name and number?

Manufacturer?

Address?

Rated capacity?............. bushels per hour.

\section{Grader No. 2.}

Trade name and number?

Manufacturer?

Address?

Rated capacity?

\begin{tabular}{l|l|l|l|}
\hline Name of Grader & No. 1 \\
Weight of Tips and Butts & \\
Weight of Graded Corn & \\
Weight of Small Corn & \\
Ter cent of Good Corn & \\
Time Started & \\
Time Finished &
\end{tabular}


FANNING MILL TEST.

\section{Instructions.}

Exercise No. 46.

Make two different tests with assigned fanning mi!l using following seeds in tests:

Clean and grade oats.

Clean and grade

Separate

from

Select sieves you think will do best and try two different sets. Record all results in table below. Seed will be supplied by instructor.

\section{Report.}

Trade name and number?

Manufacturer?

Acidress?

Date . . . . . .

\begin{tabular}{|c|c|c|c|c|c|c|}
\hline GRAINS & \multicolumn{2}{|c|}{ OATS } & \multirow[b]{2}{*}{1} & \multirow[b]{2}{*}{2} & \multirow[b]{2}{*}{1} & \multirow[b]{2}{*}{2} \\
\hline Runs & 1 & 2 & & & & \\
\hline \multicolumn{7}{|l|}{ Screen No. } \\
\hline \\
\hline \multicolumn{7}{|l|}{$\begin{array}{l}\text { Weight } \\
\text { Original Grain }\end{array}$} \\
\hline \multicolumn{7}{|l|}{ First Grade } \\
\hline \multicolumn{7}{|l|}{ Second Grade } \\
\hline \multicolumn{7}{|l|}{ Third Grade } \\
\hline \multicolumn{7}{|l|}{ Tailings } \\
\hline \multicolumn{7}{|l|}{ Time Started } \\
\hline \multicolumn{7}{|l|}{ Time Finished } \\
\hline \multicolumn{7}{|l|}{ Time Required } \\
\hline Bushels per $\mathrm{Hr}$. & & & & & & \\
\hline R. P. M. & & & & & & \\
\hline
\end{tabular}


DRAFT OF HORSE.

Inetructions.

Exercise No. 47.

Take stone boat and horse out on a smooth, level road. Attach the dynamometer between the boat and the single tree. Make the following tests:

First: With light load and height of hitch low, meilium and horizontal, make tests with close hitch.

Second: With light load and height of hitch low, medium and horizontal, make test 50 foot extension.

Third. With medium load and height of hitch low, tests with 50 foot extension.

Fifth. With maximum load and height of hitch low, medium and horizontal, make tests with close hiteh.

Sixth. With maximum load and horizontal hitch,. make tests with 50 foot extensions.

Make all measurements called for on report sheet, and record all results obtained on the same sheet. Instructor will explain how results are to be computed.

Report.

Horse (breed)?

Weight? ........

General type and buill?

Find of shoes on horse?

Height of hitch at hame?

Height of hitch at rear? low

Height of hitch at rear? low _._._._. inches; medium _........indhes; horizontal_......_inches.

Weights of loads? light_______lbs. ; medium_______lbs. maximum_......... Ibs. 


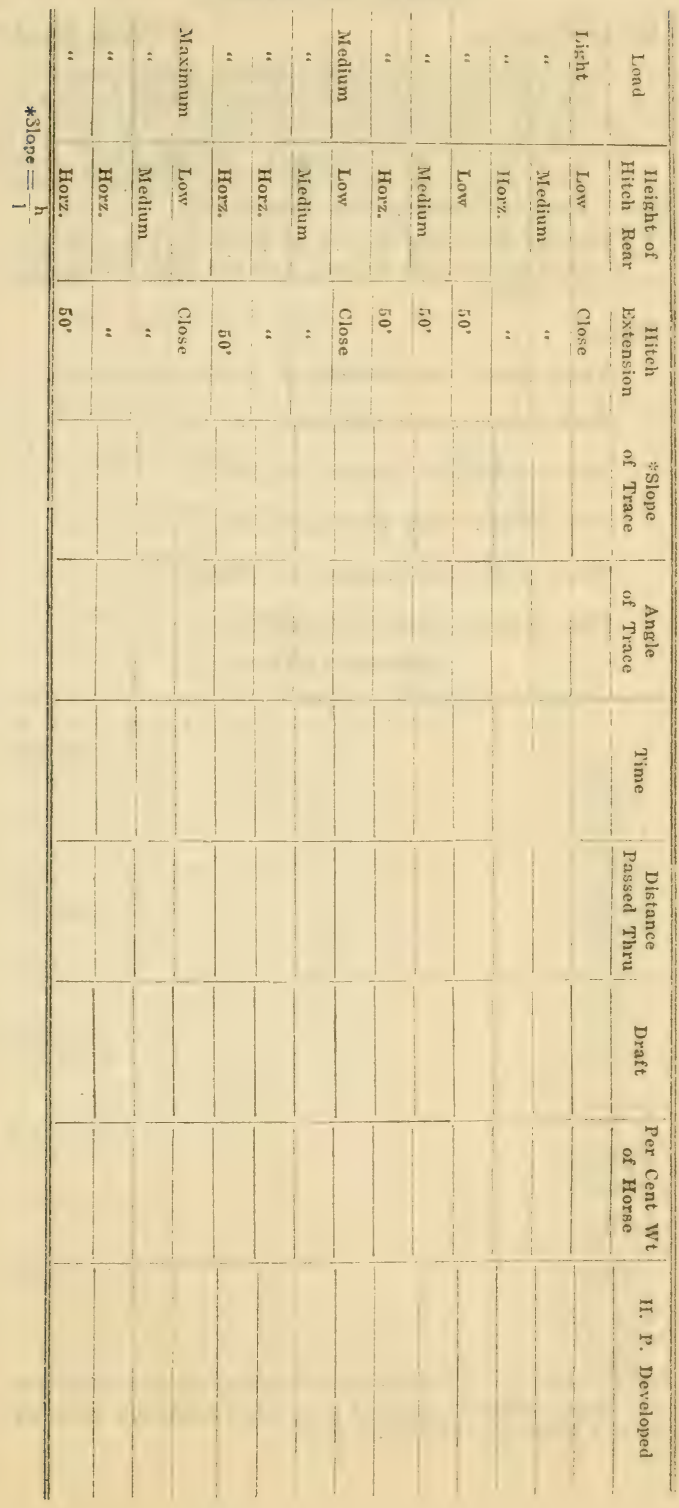




\section{DRAFT OF PLOWS}

Instructions.

Exercise No. 43

The instructor will give students instruction as to just what is to be done; the equipment to be used and the place provided for the test. The object of this excrcise is to show the influence on the draft of plows of the following: Sharpness of share, poor and good set of plow, type of plow, speel, depth of plowing and type of soil.

Fill out following report on plows and should more than three plows be used give the same information for them.

\section{Report.}

Trade name and number of plow?

Test numbers this plow used in?

Trade name and number of plow?

Test number this plow used in?

Trade name and number of plow?

Test numbers this plow used in?

Number of Tests.

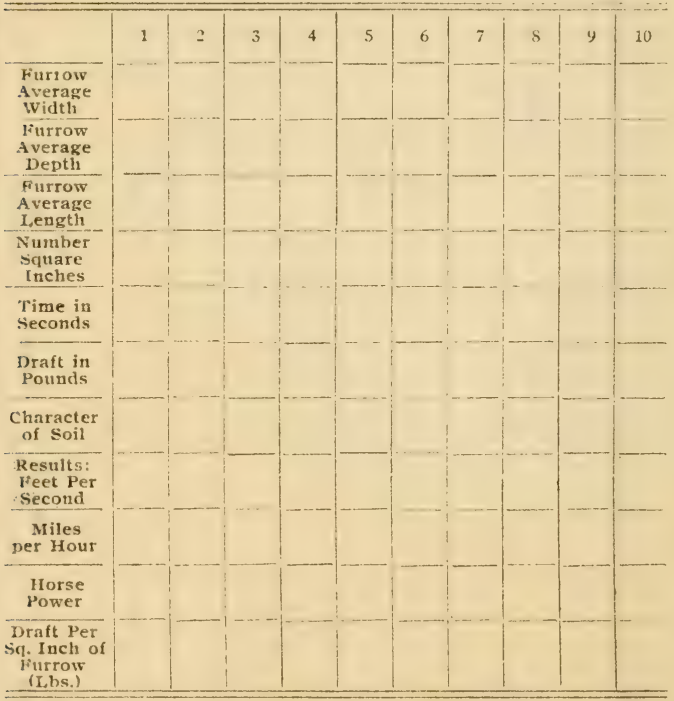

State below number of test, what condition plow was in and what was object of test. 


\section{DRAFT OF WAGONS.}

Instrucions.

Exercise No. 49.

The instructor will give student instructions as to just what is to be done, the equipment to be used and the place provided for the test. The object of this exereise is to show the factors that influence the draft of a wagon.

Fill out the following report and should more than one wagon be used, give the same information for the others.

\section{Report.}

Trade name and number of wagon?

Míanufacturer?

Address?

Width of track? inches.

Length of wheel base? ..........inches.

Weight of wagon?

Condition of wagon?

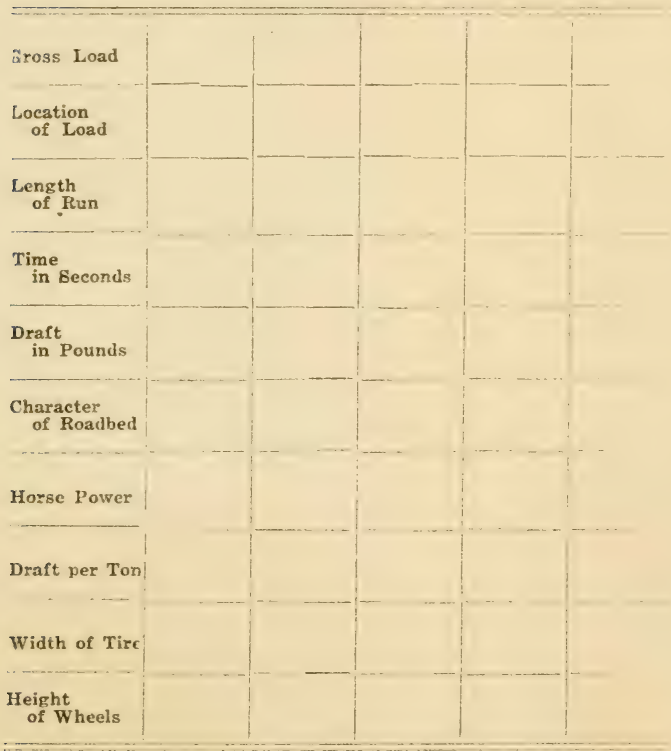


LABORATORY MANUAL.

MEMORANDUM. 
MEMORANDUM. 
MEMORANDUM. 
MEMORANDUM. 


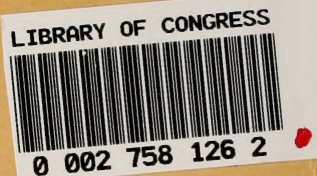

